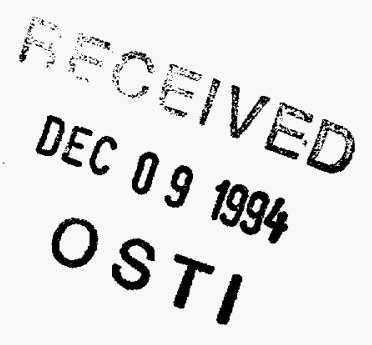

Uranium Mill Tailings Remedial ACtion PROJeCt ENVIRONMENTAL Protection IMPLEMENTATION PLAN

October 1994 
This report has been reproduced from the best available copy. Available in paper copy and microfiche.

Number of pages in this report: 51

DOE and DOE contractors can obtain copies of this report from:

Office of Scientific and Technical Information

P.O. Box 62

Oak Ridge, TN 37831

(615) 576-8401

This report is publicly available from:

National Technical Information Service

Department of Commerce

5285 Port Royal Road

Springfield, VA 22161

(703) 487-4650 
URANIUM MILL TAILINGS REMEDIAL ACTION PROJECT ENVIRONMENTAL PROTECTION IMPLEMENTATION PLAN SIGNATURE PAGE

Prepared By:

Reviewed By:

Approved By:

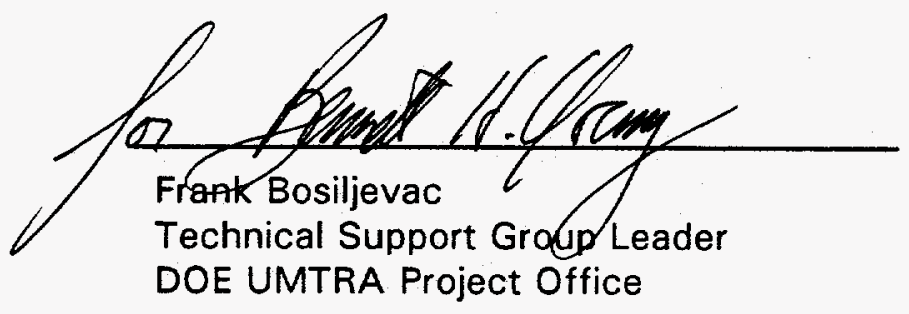

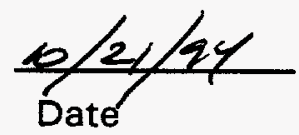
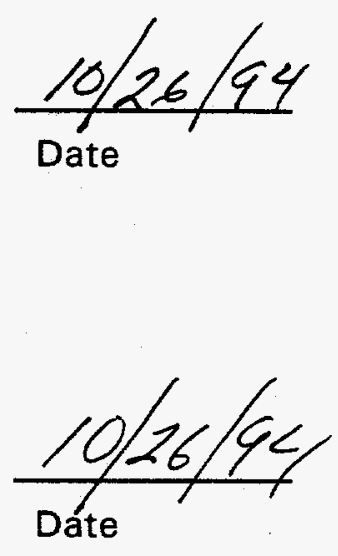


\title{
URANIUM MILL TAILINGS REMEDIAL ACTION PROJECT ENVIRONMENTAL PROTECTION IMPLEMENTATION PLAN
}

October 1994

\author{
Prepared for \\ U.S. Department of Energy \\ UMTRA Project Office \\ Albuquerque Operations Office \\ Prepared by \\ Jacobs Engineering Group Inc. \\ Albuquerque, New Mexico
}

\section{DISCLAIMER}

This report was prepared as an account of work sponsored by an agency of the United States Government. Neither the United States Government nor any agency thereof, nor any of their employees, makes any warranty, express or implied, or assumes any legal liability or responsibility for the accuracy, completeness, or usefulness of any information, apparatus, product, or process disclosed, or represents that its use would not infringe privately owned rights. Reference herein to any specific commercial product, process, or service by trade name, trademark, manufacturer, or otherwise does not necessarily constitute or imply its endorsement, recommendation, or favoring by the United States Government or any agency thereof. The views and opinions of authors expressed herein do not necessarily state or reflect those of the United States Government or any agency thereof. 


\section{DISCLAIMER}

Portions of this document may be illegible in electronic image products. Images are produced from the best available original document. 
TABLE OF CONTENTS

Section

Page

1.0 GENERAL DESCRIPTION OF THE UMTRA PROJECT ENVIRONMENTAL

PROTECTION PROGRAM $\ldots \ldots \ldots \ldots \ldots \ldots \ldots \ldots \ldots \ldots \ldots \ldots \ldots$

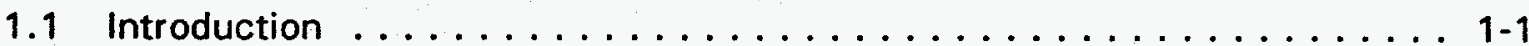

1.2 Background ............................

1.3 Goals and objectives $\ldots \ldots \ldots \ldots \ldots \ldots \ldots \ldots \ldots \ldots \ldots \ldots \ldots$

1.4 Current environmental protection program . . . . . . . . . . . 1-6

1.4.1 Program summary . . . . . . . . . . . . . . . . . . 1-6

1.4.2 DOE Headquarters baseline environmental audit . . . . . . . . . . 1-8

1.4.3 DOE Headquarters environmental management audit . . . . . . 1-8

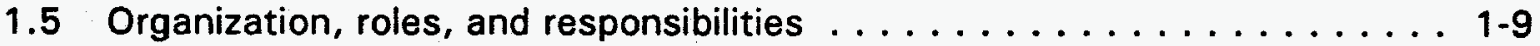

1.5.1 DOE and the UMTRA Project Office . . . . . . . . . . 1-9

1.5.2 Contractor organizations ................. 1-12

1.5.2.1 Technical Assistance Contractor . . . . . . . . . . 1-12

1.5.2.2 Remedial Action Contractor ................ 1-13

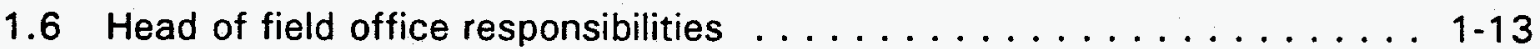

1.7 Resource and schedule summary . . . . . . . . . . . 1-19

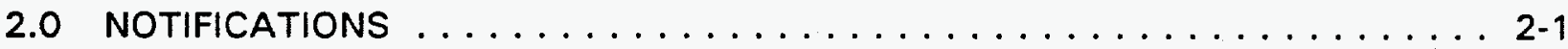

3.0 PLANNING AND REPORTING $\ldots \ldots \ldots \ldots \ldots \ldots \ldots \ldots \ldots \ldots \ldots \ldots \ldots$

3.1 Long-range environmental protection plan . . . . . . . . . . . 3-1

3.2 Annual site environmental report . . . . . . . . . . . . . . 3-1

3.3 OMB Circular A-106 ...................... 3-2

4.0 SPECIAL PROGRAMS $\ldots \ldots \ldots \ldots \ldots \ldots \ldots \ldots \ldots \ldots \ldots \ldots \ldots$

4.1 Ground Water Protection Management Program . . . . . . . . . . . . . . 4-1

4.2 Waste Minimization/Pollution Prevention Awareness Program . . . . . . . 4-2

4.3 ES\&H operating envelope program ................. . . .

5.0 ENVIRONMENTAL MONITORING PROGRAMS $\ldots \ldots \ldots \ldots \ldots \ldots \ldots$

5.1 Environmental monitoring plans ................. 5-1

5.2 Environmental monitoring activities . . . . . . . . . . . . 5-1

6.0 QUALITY ASSURANCE AND DATA VERIFICATION $\ldots \ldots \ldots \ldots \ldots \ldots$

6.1 Quality assurance program . ..................... 6-1

6.2 Laboratory certification ....................... 6-1

6.3 DOE laboratory $\mathrm{QA}$ program for radioactive material . . . . . . . . . 6-2

6.4 Independent data verification $\ldots \ldots \ldots \ldots \ldots \ldots \ldots \ldots \ldots$

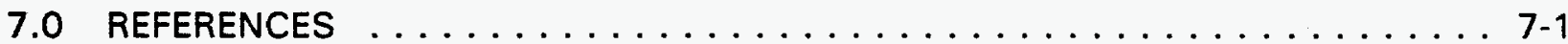

ATTACHMENT A ENVIRONMENTAL PROTECTION AT SURFACE REMEDIAL ACTION SITES 


\section{LIST OF FIGURES}

Figure

Page

1.1 UMTRA Project site locations $\ldots \ldots \ldots \ldots \ldots \ldots \ldots \ldots \ldots \ldots \ldots \ldots$ 1-2

1.2 UMTRA Project environmental, safety and health goal statement . . . . . . 1-5

1.3 Hierarchy of UMTRA Project environmental program plans and procedures . . . 1-7

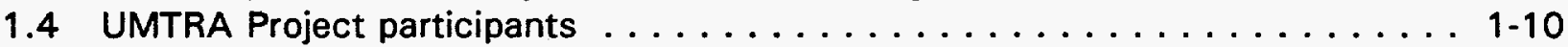

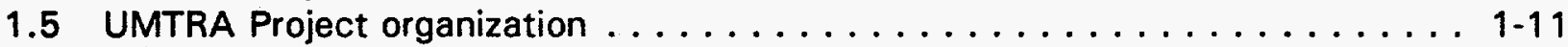

1.6 UMTRA Project Technical Assistance Contractor organization . . . . . . . . 1-14

1.7 UMTRA Project Remedial Action Contractor organization . . . . . . . . . . . . . 1-15

1.8 UMTRA Surface Project schedule . . . . . . . . . . . . . . . . . . 1-20

1.9 Estimated 5-year costs for all WBS codes for UMTRA Surface Project

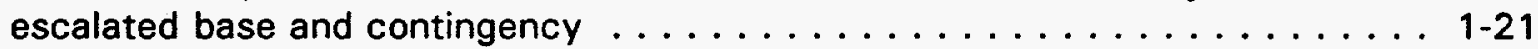

1.10 UMTRA Ground Water Project schedule . . . . . . . . . . . . . . . . . . . . 1-22

1.11 Estimated 5-year costs for all WBS codes for UMTRA Ground Water

Project escalated base and contingencr . . . . . . . . . . . . . 1-23

\section{LIST OF TABLES}

Table

Page

1.1 UMTRA Project environmental program elements $\ldots \ldots \ldots \ldots \ldots \ldots \ldots$

6.1 UMTRA Project contract laboratories . . . . . . . . . . . . . . . . 6-2 


\section{LIST OF ACRONYMS}

Acronym

AER

ALARA

CADSAR

$\mathrm{CDH}$

CDPS

DOE

DOE-AL

DOE-HO

DOI

DOT

$\mathrm{EH}-1$

EH-24

EM

EMP

EPA

EPCRA

EPIP

ES\&H

FY

GJPO

LTSP

NEPA

NESHAP

NPDES

NRC

OMB

ORNL

ORPS

PEIS

PO

QA

QAPP

RAC

RAP

RRM

SOP

SOWP

TAC

TAD

TAGR

TSP

UMTRA

UMTRCA

\section{Definition}

Annual Environmental Report

as low as reasonably achievable

Comparative Analysis of Disposal Site Alternatives

Colorado Department of Health

Colorado Discharge Permit System

U.S. Department of Energy

DOE Albuquerque Operations Office

DOE Headquarters

U.S. Department of the Interior

U.S. Department of Transportation

DOE Assistant Secretary for Environment, Safety, and Health

DOE Office of Environmental Audit

DOE Office of Environmental Management

Environmental Monitoring Plan

U.S. Environmental Protection Agency

Emergency Planning and Community Right-to-Know Act

Environmental Protection Implementation Plan

environment, safety, and health

fiscal year

Grand Junction Projects Office

Long-Term Surveillance Plan

National Environmental Policy Act

National Emissions Standards for Hazardous Air Pollutants

National Pollutant Discharge Elimination System

U.S. Nuclear Regulatory Commission

Office of Management and Budget

Oak Ridge National Laboratory

Occurrence Reporting and Processing System

programmatic environmental impact statement

Project Office

quality assurance

Quality Assurance Program Plan

Remedial Action Contractor

remedial action plan

residual radioactive material

standard operating procedure

site observational work plan

Technical Assistance Contractor

Technical Approach Document

Technical Approach to Groundwater Restoration

total suspended particulates

Uranium Mill Tailings Remedial Action

Uranium Mill Tailings Radiation Control Act 


\section{LIST OF ACRONYMS (Concluded)}

Acronym

WBS

WM/PPAP

\section{Definition}

work breakdown structure

Waste Minimization/Pollution Prevention Awareness Program 


\subsection{GENERAL DESCRIPTION OF THE UMTRA PROJECT ENVIRONMENTAL PROTECTION PROGRAM}

\section{$1.1 \quad$ INTRODUCTION}

The Uranium Mill Tailings Remedial Action (UMTRA) Project Environmental Protection Implementation Plan (EPIP) has been prepared in accordance with the requirements of the U.S. Department of Energy (DOE) Order 5400.1. The UMTRA EPIP is updated annually. This version covers the time period of 9 November 1994, through 8 November 1995. Its purpose is to provide management direction to ensure that the UMTRA Project is operated and managed in a manner that will protect, maintain, and where necessary, restore environmental quality, minimize potential threats to public health and the environment, and comply with environmental regulations and DOE policies.

\subsection{BACKGROUND}

The Uranium Mill Tailings Radiation Control Act (UMTRCA) of 1978 (42 USC $\$ 7922$ et seq.) authorizes the DOE to undertake remedial actions at 24 designated inactive uranium processing sites and associated vicinity properties. As a result, the UMTRA Project was formed and placed under the direction of the DOE Albuquerque Operations Office (DOE-AL). The UMTRCA directs that ". . . every reasonable effort be made to provide for stabilization, disposal and control of the tailings in a safe and environmentally sound manner to ensure public health, safety and welfare."

The 24 designated inactive uranium mill tailings sites are located in 10 states and on Indian lands. Figure 1.1 shows the locations of these sites. Although the 24 UMTRA Project sites are geographically separate, they are considered a single installation for purposes of administration and environment, safety, and health (ES\&H) program implementation.

In addition, there are over 5000 vicinity properties being remediated in conjunction with the designated sites. Remediation of the vicinity properties is administered and budgeted through the UMTRA Project Office (PO). Most of these remediation activities are performed in Grand Junction, Colorado, by the DOE Grand Junction Projects Office (GJPO), which is also under the direction of the DOE-AL. The remainder of the vicinity property remediation is performed by MK-Ferguson, the UMTRA Remedial Action Contractor (RAC). Vicinity property remediation handled by the GJPO will be covered in the GJPO EPIP (DOE, $1994 a)$. Only the implementation of the environmental protection program for the designated inactive mill sites and remaining vicinity properties is discussed in the UMTRA Project EPIP. 


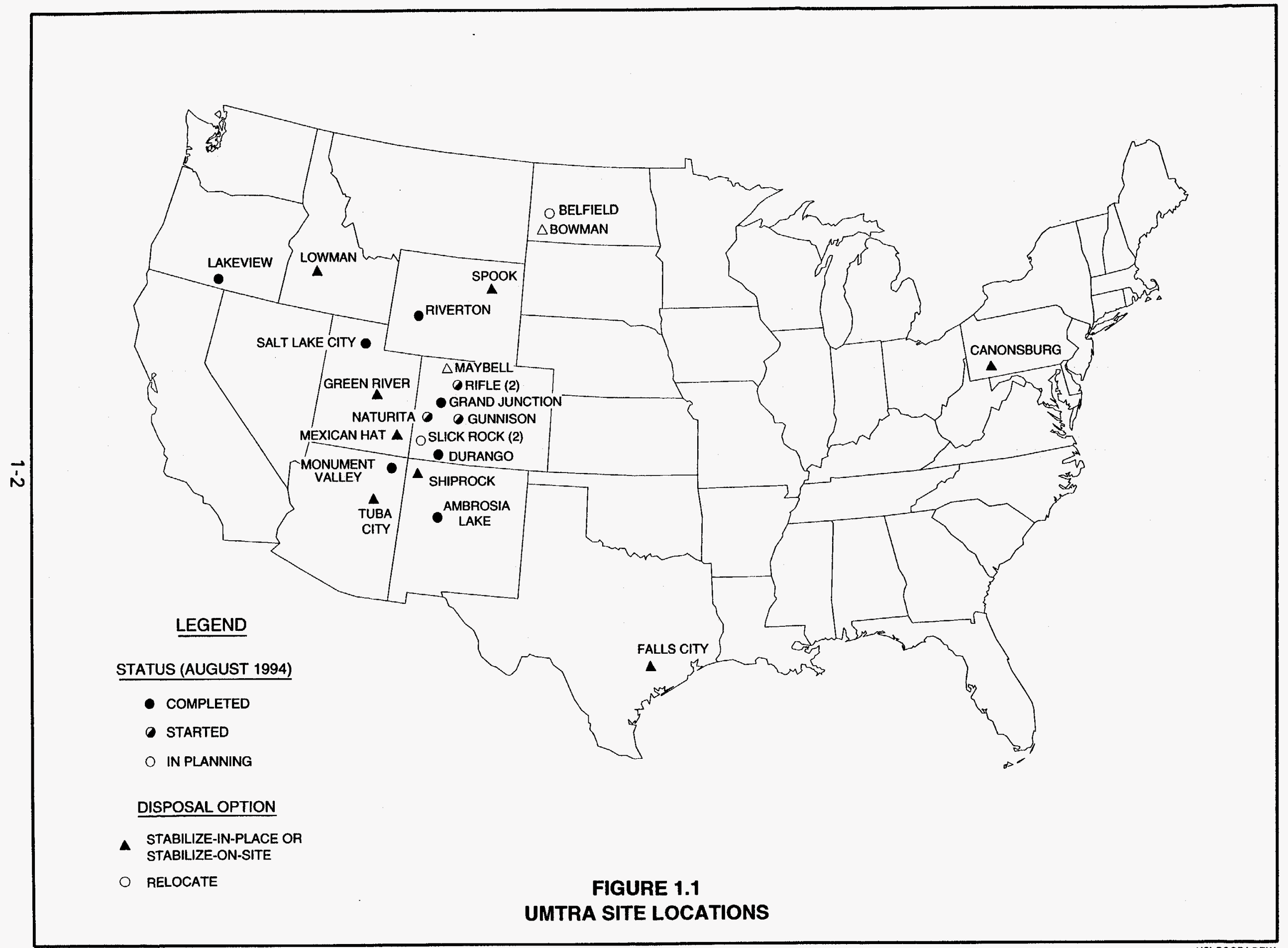


The purpose of the remedial actions is to stabilize and control the uranium mill tailings and other residual radioactive materials (RRM) in a safe and environmentally sound manner in order to minimize radiation health hazards to the public. Pursuant to the UMTRCA, the remedial actions undertaken by the DOE are to be accomplished:

- With the full participation of the affected states and Indian tribes.

- In accordance with standards issued by the U.S. Environmental Protection Agency (EPA) for the UMTRA Project.

- With the concurrence of the U.S. Nuclear Regulatory Commission (NRC).

The EPA established health and environmental protection standards (40 CFR Part 192) to control radiation emissions and to remediate and prevent further contamination of ground water beneath and in the vicinity of inactive uranium processing sites, uranium mill tailings piles, and disposal cells. The EPA has proposed ground water protection standards (52 FR 36000 (1987)) that call for the DOE to either 1) document that the ground water quality meets the stated standards without remediation for each affected site or 2) remediate the contaminated ground water until it meets the applicable standards. The final rule is under review by the Office of Management and Budget.

The UMTRA Surface Project has been designated by the DOE as a major system acquisition under the non-defense Environmental Restoration Program because of its importance and budget requirements. Surface remedial action is actively under way or completed at most sites (Figure 1.1). The UMTRCA currently terminates authorization to conduct surface remedial action at the end of fiscal year (FY) 1996. The UMTRA Ground Water Project, which is a separate major project, began in 1991 and is in its early planning stages. A draft programmatic environmental impact statement (PEIS) as been approved by DOE-HO.

While the sites for the UMTRA Ground Water Project are the same as for the UMTRA Surface Project, the extent of ground water remediation required at each site and the priorities for ground water cleanup will be determined after each site has been assessed and comments from affected states, Indian tribes, and the public have been received. Unlike the 1996 limit on the surface remedial action program, the UMTRCA does not limit the period for conducting ground water restoration.

\subsection{GOALS AND OBJECTIVES}

The UMTRA Project is an environmental remediation program designed to minimize or eliminate environmental and public health hazards. The UMTRA Project's overall goal is to clean up and control tailings from inactive uranium mills in a safe and environmentally sound manner to eliminate current and potential environmental and public health hazards associated with these tailings. These hazards include exposure to radium, radon, thorium, uranium, and other 
contaminants associated with the processing of uranium mill tailings. Specifically, the objectives of the UMTRA Surface and UMTRA Ground Water projects are to:

- Reduce or eliminate public health and environmental risks from radioactive, hazardous, and toxic constituents in uranium mill tailings and tailings-contaminated materials by meeting the EPA standards in 40 CFR Part 192.

- Ensure that environmental protection is adequately addressed in the selection and implementation of remedial actions, and that provisions of the National Environmental Policy Act (NEPA) (42 USC $\$ 4321$ et seq.), as implemented by the DOE in 10 CFR Part 1021, are satisfied.

- Perform remedial actions at the designated inactive uranium processing sites and vicinity properties in a safe and environmentally sound manner and in accordance with all applicable federal, tribal, state, and local ES\&H requirements.

- Return all former processing sites to a condition suitable for unrestricted use, except for that portion necessary to contain any tailings disposal cell that may remain.

- Prepare long-term surveillance plans (LTSP) for tailings disposal sites and have each site included under the general NRC license in accordance with 10 CFR Part 40.

The UMTRA PO's environmental policy is to conduct Project operations in compliance with all applicable Federal, state, and local environmental regulations, laws, DOE Orders, and other requirements, as required by the DOE-AL Environmental Policy Statement (DOE, 1992a). The PO is committed to providing sound environmental management to all Project sites; correcting existing environmental problems before they deviate from regulatory requirements or pose a threat to the quality of the environment; and minimizing the generation of contaminants, wastes, and other residual materials requiring disposal or release to the environment. The UMTRA PO has stated its commitment to sound environmental management in the UMTRA Project ES\&H goal statement (Figure 1.2) (DOE, 1992b).

In addition, the UMTRA PO has set three environmental goals in the UMTRA Project ES\&H plan (DOE, 1992c):

1. Environmental Protection Goal-Environmental releases from Project operations should be kept below permit and other applicable requirements.

2. Environmental Compliance Goal-There should be no violations of environmental permits or regulations. 
The DOE's Uranium Mill Tailings Remedial Action (UMTRA) Project is a remediation and environmental protection program. The Project's congressionally mandated mission is to clean up and control residual radioactive materials from designated inactive uranium processing sites and to eliminate present and future environmental health hazards that may result from those materials. The UMTRA Project's goal is to achieve its mission in a manner which protects public health and safety and the environment; ensures the safety and health of workers; and meets or exceeds the requirements of all Federal, state, and local laws, regulations, orders, and permits, utilizing best management practices. To achieve this goal, the UMTRA Project Office has prepared and is implementing an UMTRA Project Environmental, Health, and Safety Plan.

The UMTRA Project remains firmly committed to implementing national environmental protection policies and goals while following the most technologically advanced safety and health policies and goals. Accordingly, the UMTRA Project Office's policy is to conduct operations in compliance with both the letter and the spirit of applicable environmental, safety and health statutes, regulations, and standards and to strive for excellence rather than just compliance. In addition, the UMTRA Project is committed to sound environmental management and worker safety practices; minimizing the risks to the environment, the public, and workers; and anticipating and addressing potential problems before they pose a threat to the environment or the public.

The UMTRA Project Office is committed to undertaking appropriate measures to minimize the generation of contaminants, wastes, and other residual materials requiring disposal or release to the environment through source reduction, recycling, treatment, and pollution prevention.

Protection of the environment, workers, and the public are of paramount importance to the DOE and the UMTRA Project. Project activities have always recognized this, and as a result, the Project experiences a level of public trust not evident in many environmental restoration endeavors. It is the UMTRA Project Office's policy that its contractors shall incorporate this commitment to worker safety and environmental management in all of their activities. The Project Office requires its contractors to conduct their operations in an environmentally sound and safe manner that keeps the risks to the environment, workers, and the public as low as reasonably achievable and actively oversees contractors' activities to ensure compliance with this policy.

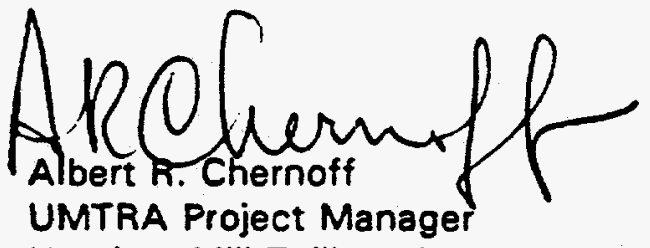

Uranium Mill Tailings Remedial Action Project Office 
3. Environmental Restoration Goal-Remedial actions at processing sites and vicinity properties should result in the 40 CFR Part 192 cleanup standard requirements being met, at a minimum.

\subsection{CURRENT ENVIRONMENTAL PROTECTION PROGRAM}

\subsubsection{Program summary}

The relationship of the various elements of the UMTRA Project environmental protection program, as reflected in the various compliance and monitoring plans and guidance documents, is presented in Figure 1.3 and the schedule for their review and periodic revision is presented in Table 1.1. The UMTRA PO has implemented all environmental protection program elements required by DOE Order 5400.1.

Table 1.1 UMTRA Project environmental program elements

\begin{tabular}{ll}
\hline \multicolumn{1}{c}{ Document } & \multicolumn{1}{c}{ Review and revision cycle } \\
\hline UMTRA Project ES\&H Goal Statement & Annual review. \\
Waste Minimization and Pollution Prevention & Annual review; update every 3 years. \\
Awareness Program Plan & \\
UMTRA Project ES\&H Plan & Annual review; update as needed. \\
$\begin{array}{l}\text { Groundwater Protection Management } \\
\text { Program Plan }\end{array}$ & Annual review; update every 3 years. \\
Environmental Monitoring Plan & Annual review; update every 3 years. \\
\hline
\end{tabular}

The UMTRA Project ES\&H goal statement (DOE, 1992b) is discussed in Section 1.3.

The UMTRA PO has in place an UMTRA Project ES\&H plan (DOE, 1992c) that directs the PO's Technical Assistance Contractor (TAC), Jacobs Engineering Group Inc., and the RAC to implement ES\&H policies and goals. The ES\&H plan describes the UMTRA Project ES\&H standards, program requirements, radiation control and monitoring, environmental monitoring, and industrial hazards control program. The ES\&H plan is periodically revised to reflect current guidelines and experience gained.

To better assist the PO in meeting its ES\&H goals, the UMTRA Project ES\&H Committee was established in FY 1992. The ES\&H Committee, which is chaired by the UMTRA PO ES\&H Manager and has TAC, RAC, and GJPO representatives, meets monthly. One of the responsibilities of the Committee is to deal with environmental protection issues affecting the Project. Other environmental protection program elements are discussed in greater detail in Sections 2.0 through 6.0 . 


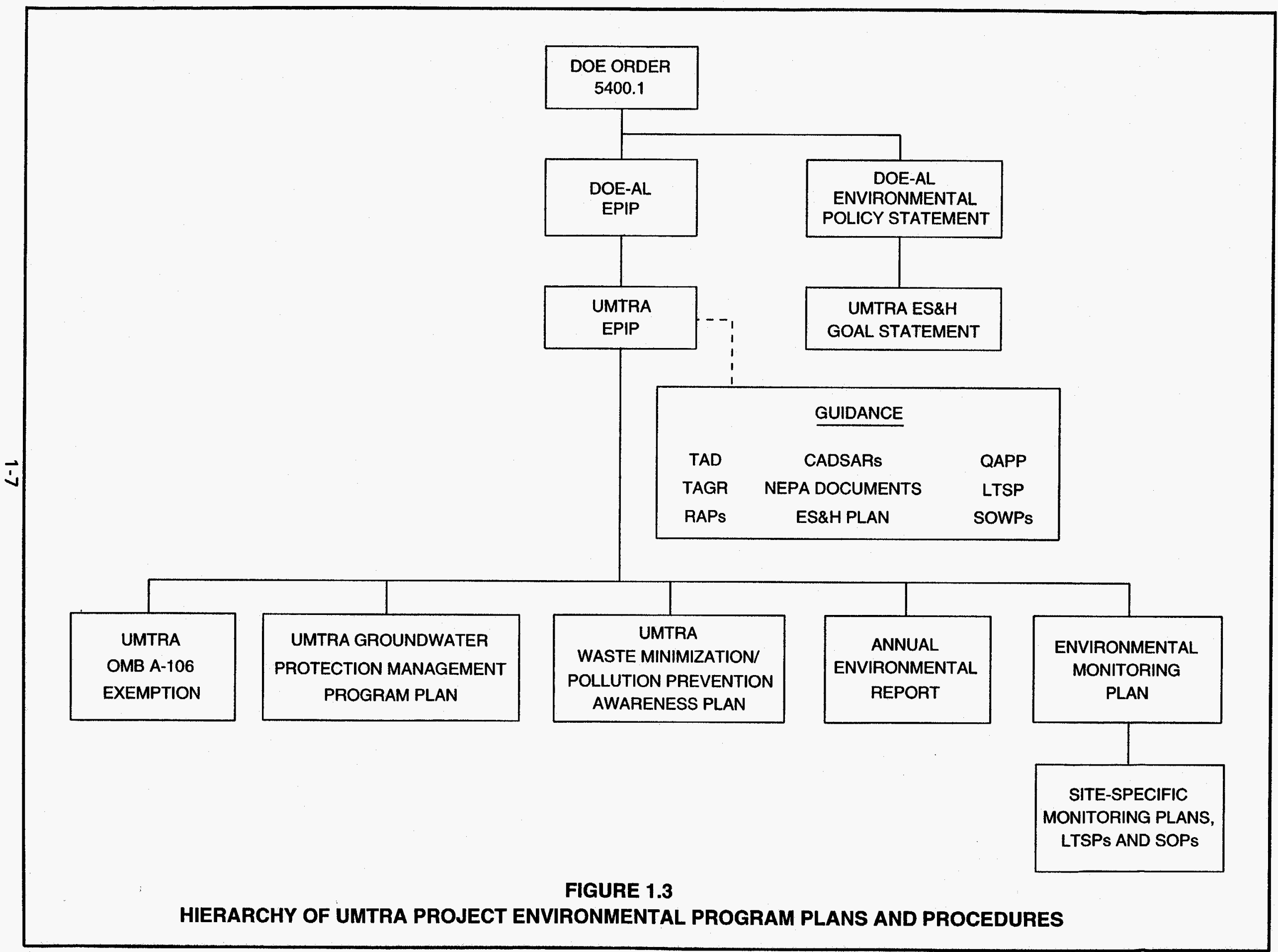




\subsubsection{DOE Headquarters baseline environmental audit}

The DOE Office of Environmental Audit (EH-24) conducted a baseline environmental audit of the UMTRA Project in June 1991. The scope of the audit covered all areas of environmental activities and waste management operations, with the exception of NEPA compliance. Compliance with federal, state, and local regulations; DOE Orders; and internal facility requirements was assessed, along with adherence to best management practices.

The baseline environmental audit identified 48 findings (DOE, 1991a). The findings were divided between 32 compliance findings and 16 best management practices. None of these findings, however, reflected situations that presented an immediate danger to the public health or the environment.

The UMTRA PO responded with an action plan (DOE, 1991b) that defines responsibilities and describes the organization and management structures to be used to implement the action plan. The plan identifies actions that will correct the deficiencies found by the audit as well as the underlying root causes. Implementation of the action plan has resulted in significant improvement in UMTRA Project compliance with environmental regulations. With the successful completion of the corrective actions during FY 1994, the UMTRA Project has closed the baseline environmental audit.

\subsubsection{DOE Headquarters environmental management audit}

The EH-24 conducted an environmental management audit of the UMTRA Project during October and November 1992. The scope of the audit was comprehensive and covered all areas of environmental management by the UMTRA PO and GJPO, except for NEPA implementation.

The environmental management audit identified 18 findings, broken into 11 compliance findings and 7 best management findings (DOE, 1993a). No findings presented immediate danger to the environment or public health. Overall, the conclusion was that the UMTRA Project has made excellent progress in implementing and developing environmental protection programs.

An action plan was prepared to address the findings and identify corrective actions (DOE, 1993b). The plan assigns responsibility to the affected organization, along with a designated DOE UMTRA oversight person. The action plan was approved by the DOE Office of Environmental Restoration prior to release to the Assistant Secretary for Environment, Safety, and Health $(E H-1)$. All actions were assigned a priority ranking according to priority definitions developed for Tiger Team action plans. Priority 1 action items will be aggressively pursued by the UMTRA PO.

By the end of FY1994, the UMTRA Project completed the majority of the corrective actions. During FY1995, all corrective action documentation will be 
compiled for review and approval and the environmental management audit will be closed.

By adhering to these corrective actions, environmental programs on the UMTRA Project will be significantly enhanced.

\subsection{ORGANIZATION, ROLES, AND RESPONSIBILITIES}

This section presents information on the organization and management structure of the DOE offices and contractor organizations participating in the UMTRA Project, including environmental protection activities. Figure 1.4 shows the overall organizational relationships of the UMTRA Project participants.

\subsubsection{DOE and the UMTRA Project Office}

The DOE Office of Environmental Management (EM) has full responsibility and authority for the management, planning, and conduct of UMTRA Surface Project and UMTRA Ground Water Project activities. The EM's Office of Southwestern Area Programs, Off-Site Program Division has been assigned Headquarters' responsibilities for the program. The Division Director serves as the Program Manager.

The DOE-AL Manager has been assigned the responsibility and authority for the field management of the Project, which includes the line management authority, responsibility, and accountability for overall Project management and contract administration in a manner consistent with approved legislation, scope, and baselines. Under the current DOE-AL organization and structure, responsibility for management of the Project within the DOE-AL has been assigned to the Office of Environment/Project Management. The DOE's day-to-day responsibility for planning, coordinating, and conducting remedial actions at the uranium mill tailings sites and associated vicinity properties has been assigned to the UMTRA PO. Matrix support available to the UMTRA Project Manager, as required, from the DOE-AL organization includes legal, procurement, budget, finance, quality assurance ( $Q A$ ), property management, health and safety, environmental protection, safeguards and security, and public affairs.

The policy and guidance for carrying out the mission of the UMTRA Project are provided by the UMTRA PO. However, some of the vicinity-property-related portions of the UMTRA mission are carried out by the GJPO and by Oak Ridge National Laboratory (ORNL).

The organization, operation, and responsibilities of the UMTRA PO are based on a minimally staffed office, with DOE-AL matrix support (Figure 1.5). The UMTRA PO is responsible for making key Project decisions and for managing the contractors engaged to do the actual work. The UMTRA PO is accountable to DOE-AL and DOE-Headquarters (DOE-HO) management for the successful accomplishment of the Project. 


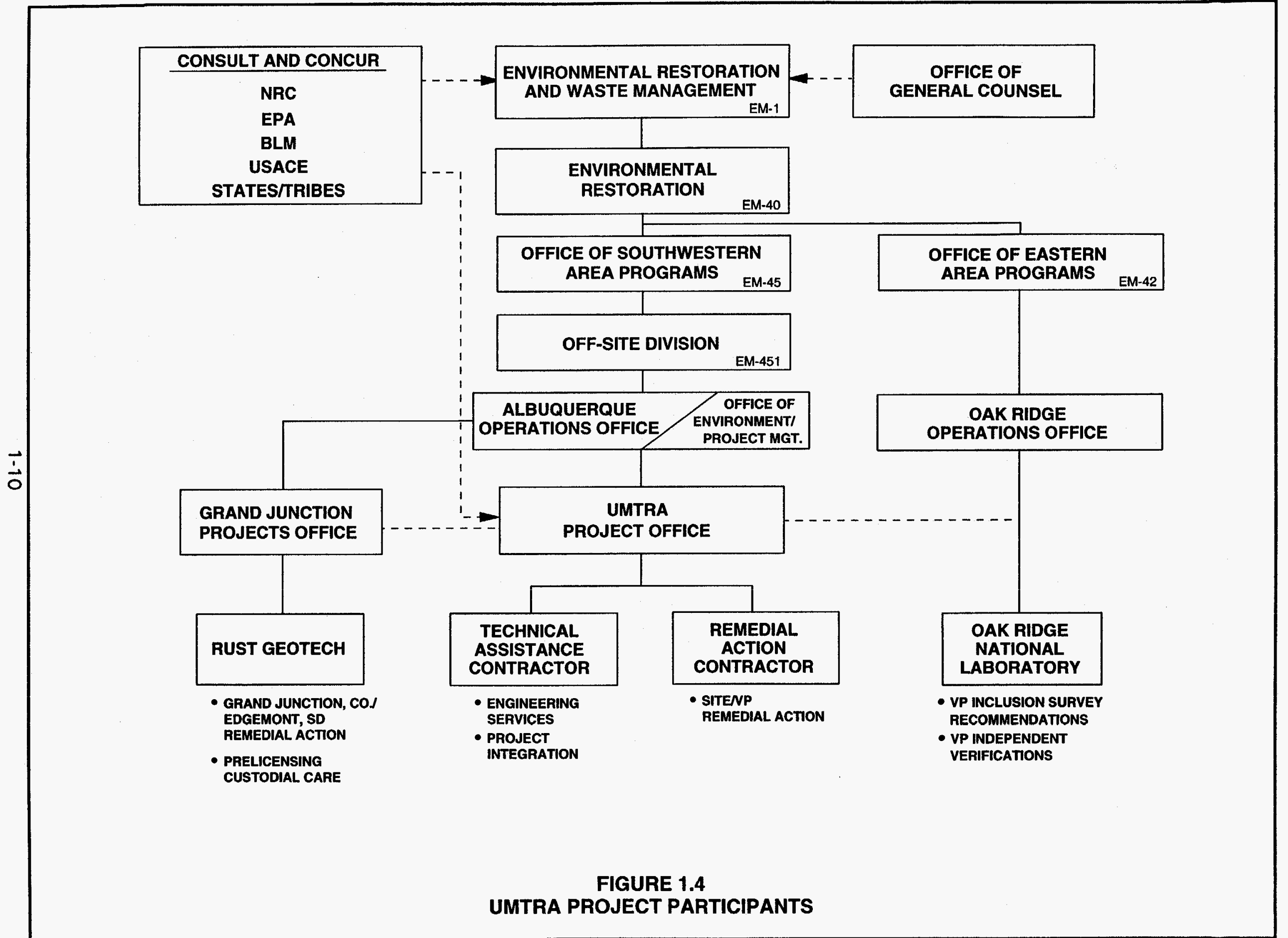




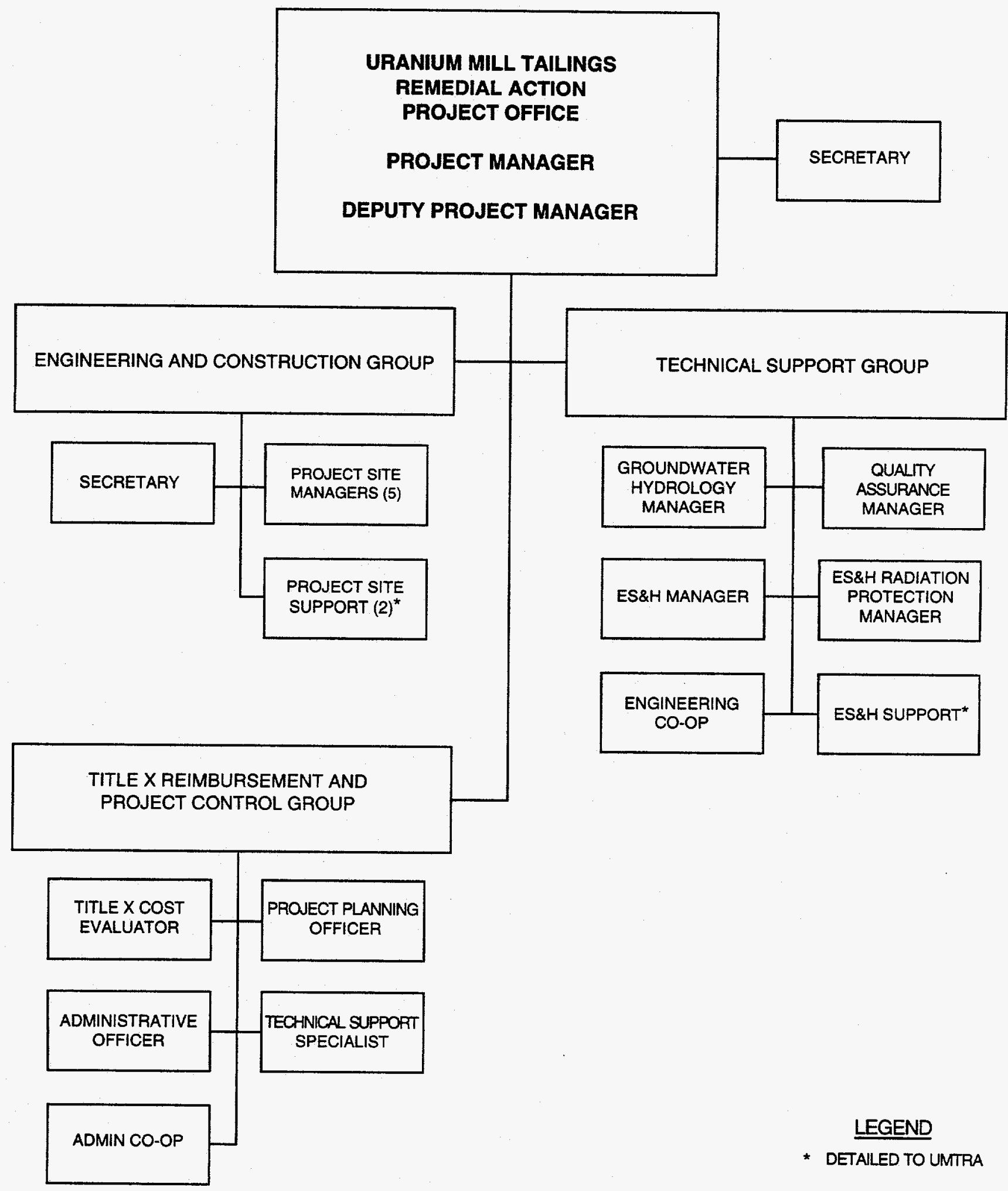

FIGURE 1.5

UMTRA PROJECT ORGANIZATION 
The UMTRA PO Manager and Deputy Manager are supported by three Group Leaders. Within the UMTRA PO, line management, which is responsible for ES\&H compliance, flows from the Project Manager through the Deputy Project Manager to the Engineering and Construction Group. The Technical Support Group provides Project ES\&H oversight, while the DOE-AL Office of Environment, Safety, and Health has an independent oversight role that involves defining requirements and auditing for compliance.

The Engineering and Construction Group Leader is responsible for managing remedial action planning and execution at all UMTRA Project sites, including construction oversight, design review, cost control, interface with the NRC and the participating states and Indian tribes, and site/vicinity property management. The Engineering and Construction Group is considered the line organization, and is, therefore, accountable for compliance with ES\&H regulations.

The Technical Support Group Leader is responsible for managing technical support functions, including ground water program management, ES\&H oversight, QA, and NEPA documentation. The Project Control Group Leader is responsible for managing project activities involving budget, schedule, finance, administration, personnel, real and personal property management, state cooperative agreements, and the Project long-range planning.

\subsubsection{Contractor organizations}

For the UMTRA Surface Project, the UMTRA PO is assisted by the TAC and the RAC, a vicinity property Inclusion Survey Contractor, and a Grand Junction vicinity property RAC. The Grand Junction RAC, RUST Geotech, and the Inclusion Survey Contractor, ORNL, are managed by the GJPO and their responsibilities are discussed in the GJPO EPIP (DOE, 1994a). The TAC is the only contract organization assisting the UMTRA PO with the UMTRA Ground Water Project at the present time, providing technical assistance and Project integration services. The UMTRA Surface Project RAC, MK-Ferguson Company, is responsible for performing design and surface remedial action. The UMTRA Ground Water Project RAC has yet to be determined.

\subsubsection{Technical Assistance Contractor}

The resources and expertise required to accomplish the responsibilities of the TAC are provided by Jacobs Engineering Group Inc., and its subcontractors Roy F. Weston, Inc.; Geraghty \& Miller, Inc.; and AGRA Earth \& Environmental. The TAC is responsible for development, implementation, and operation of Projectlevel programs for ES\&H, QA, public participation and information, document control, and cost and schedule control and integration.

The TAC also provides technical support. These activities include characterizing and monitoring ground water at UMTRA Project sites; monitoring radon off the site; monitoring technology development; coordinating the NEPA review process and preparation of appropriate NEPA compliance documentation; developing 
remedial action concepts, conceptual designs, remedial action selection reports, and remedial action plans; conducting special studies; addressing all ground water protection issues and developing ground water protection strategies; reviewing final designs and providing technical assistance during construction; recommending certification of remedial action and coordinating site licensing; and conducting pre-licensing surveillance and monitoring at disposal sites.

The TAC provides technical and management support to both the surface and ground water portions of the Project through the use of a matrix management structure (Figure 1.6). The TAC organization structure reflects the multidisciplinary nature of its assigned scope of work.

\subsubsection{Remedial Action Contractor}

MK-Ferguson Company is contractually responsible as the surface RAC for the UMTRA Project sites. MK-Ferguson is supported by Chem-Waste Management Federal Environmental Services, Inc., which provides technical support for management of the health physics and radiation protection programs, and MK Environmental Services Division, which provides design services, engineering support during construction, environmental permitting support, and completion report support.

The RAC performs overall construction management services in the areas of design, engineering, construction, cost control, procurement, $\mathrm{QA}$, subcontract administration, and ES\&H. The RAC manages these activities in close cooperation and coordination with the DOE, and ensures that end results meet specified and required environmental protection goals.

The RAC's organizational structure is headed by the Project Director and includes all key functions (Figure 1.7). The Project Director provides overall direction to all Project activities and long-range planning.

\subsection{HEAD OF FIELD OFFICE RESPONSIBILITIES}

DOE Order 5400.1 assigns 13 responsibilities to the heads of field organizations, such as the DOE-AL. This section describes how these responsibilities are fulfilled on the UMTRA Project.

1. Issue and update, as required, a general environmental statement that reflects the statement of policy in this order and contains broad environmental protection goals for all facilities and activities for which an individual is responsible.

The Manager of DOE-AL, Bruce G. Twining, has issued a DOE-AL Environmental Policy Statement (DOE, 1992a). The salient elements of this policy have been incorporated into the UMTRA Project ES\&H plan (DOE, 1992c) and the UMTRA Project ES\&H goal statement (DOE, 1992b). The UMTRA PO oversees contractor activities to ensure compliance with 


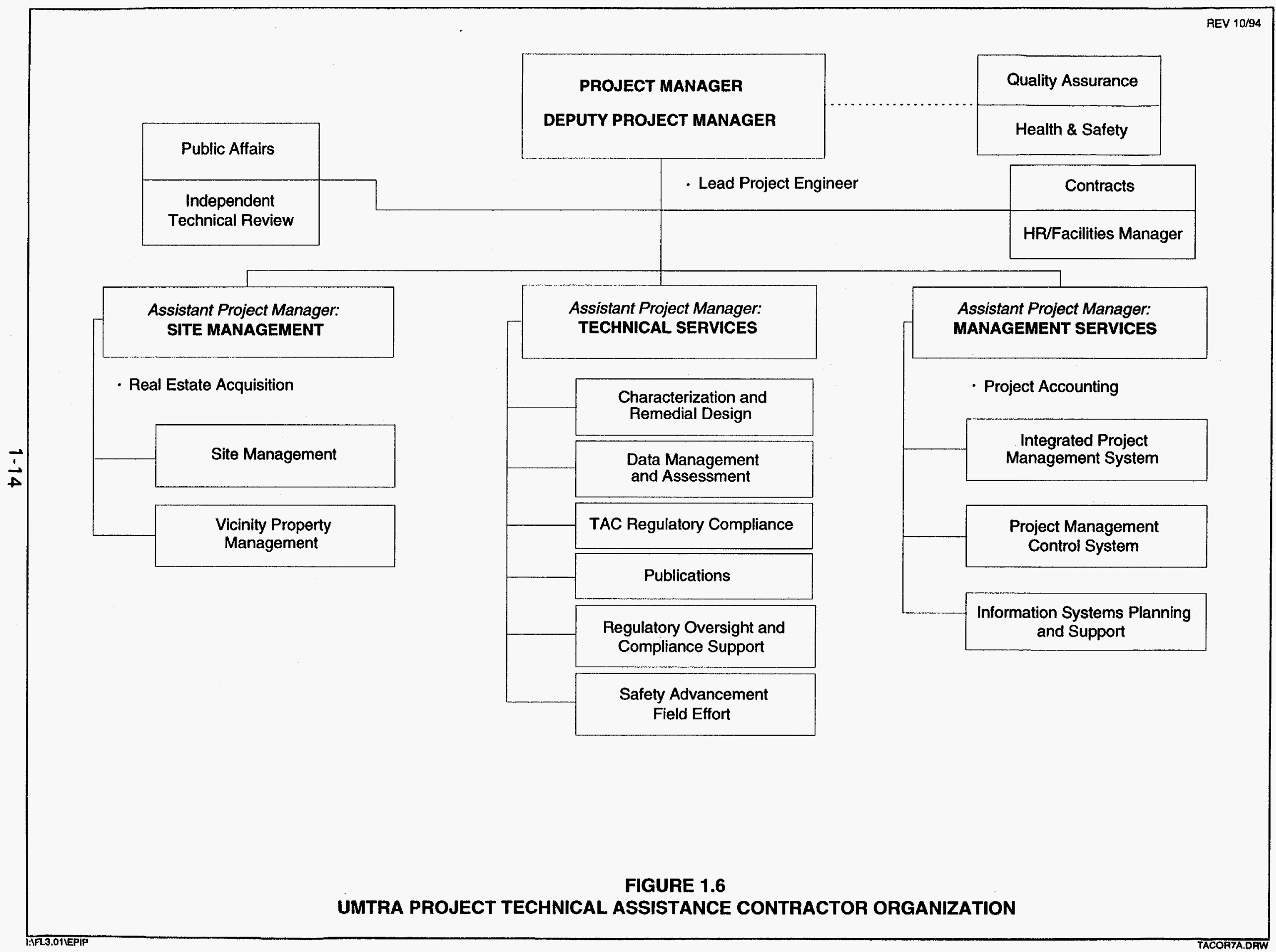




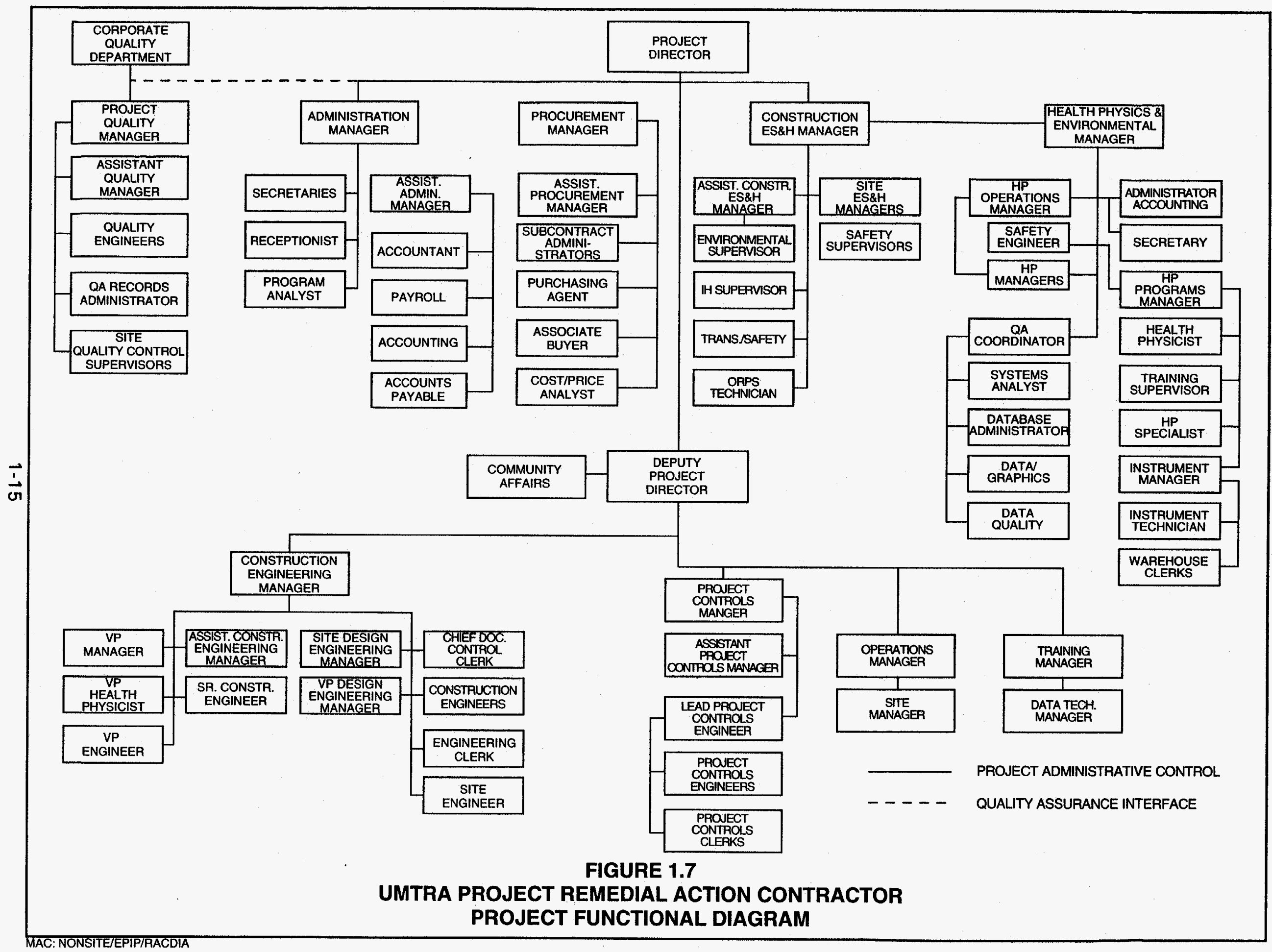


these documents. The UMTRA PO's ES\&H plan and goal statement will be reviewed annually along with the EPIP.

2. Ensure that all operations under their authority comply with applicable environmental protection laws, regulations, and directives.

The UMTRA PO has an ES\&H manager and site managers who are responsible for ensuring that all UMTRA Project operations comply with environmental laws, regulations, and directives. The RAC and the TAC also are responsible for adhering to all environmental laws, regulations, and directives. Compliance is accomplished by performing appropriate characterization studies of materials found on UMTRA Project sites, environmental monitoring, and periodic environmental audits at all UMTRA Project construction sites.

The UMTRA PO is maintaining a regulatory compliance operating envelope database to document the applicability of and compliance with ES\&H regulations. The Project continually reviews applicable regulations and identifies any steps necessary to ensure complete compliance. Any variances or exceptions will be documented. If complete compliance cannot be achieved technically or is not warranted due to programmatic circumstances, contractors are to prepare an exemption request for UMTRA PO review. If the UMTRA PO determines that an exemption is warranted, the exemption procedure in DOE Order 5400.1, Chapter I, shall be followed. When appropriate, the UMTRA PO consults with DOE-HQ and DOE-AL concerning regulatory exemptions.

3. Identify significant environmental compliance issues that require resolution and coordination, and advise the EH-1 and Headquarters program elements promptly.

UMTRA Project environmental compliance issues were identified during the $1991 \mathrm{EH}-24$ baseline environmental audit and the $1992 \mathrm{EH}-24$ environmental management audit. Corrective action plans were prepared by the UMTRA PO and submitted to DOE-HO for approval.

The UMTRA PO has an ES\&H Committee, which provides support in resolving compliance issues identified by audits, and identifying and resolving future environmental compliance issues facing the Project. The Committee meets monthly and its activities are tracked and reported to Project participants including, if appropriate, DOE-HO.

4. Ensure that all required environmental permits are secured from the appropriate regulatory agency promptly. Consistent with the requirement of DOE Order 5400.2A, in negotiating the terms and conditions of permits, settlements, consent orders, consent decrees, and other legal or administrative documents, every effort shall be made to ensure that permit requirements and conditions reflect the requirements of environmental 
regulations, are consistent with national security interests, and are costeffective.

The primary responsibility on the UMTRA Project for seeking, obtaining, and implementing environmental clearances, permits, consultations, and approvals during the NEPA compliance phase rests with the TAC. The primary responsibility on the UMTRA Project for seeking, obtaining, and implementing construction and remedial action-related environmental permits rests with the RAC. The UMTRA Project has cooperative working relationships with federal, state, tribal, and local government offices with permitting responsibilities and regularly reviews compliance requirements.

5. Conduct environmental appraisals of programs, projects, and facilities in accordance with DOE Order 5482.1B and other ES\&H requirements, and provide copies of appraisal reports to the EH-1 and the appropriate program office.

The UMTRA PO, supported by the TAC, conducts environmental and health \& safety audits of the RAC at UMTRA Project sites under construction. Copies of these audits are kept internal to the UMTRA Project. However, primary responsibility for the environmental appraisal program lies with the DOE-AL Environmental Protection Division, which provides copies of its appraisal reports to the EH-1.

6. Establish and maintain liaison and cooperative programs with appropriate federal, regional, state, and local environmental officials so as to facilitate effective environmental management.

The UMTRA PO has cooperative working relationships with all participating federal, regional, state, tribal, and local environmental officials regarding the UMTRA Project sites. As required by the UMTRCA, the DOE has cooperative agreements in place with each state or Indian tribe affected by the Project. Each party's (the state or Indian tribe, and the DOE) responsibility for funding, acquisition of the mill tailings site, final design concurrence, and remedial action is defined in the cooperative agreements. The UMTRA Project holds public meetings to solicit public concerns about UMTRA Project activities in their communities. The importance of open communication is stressed to keep all participants abreast of concerns, problems, and resolutions.

7. Develop and implement programs that direct contractors to execute environmental protection compliance programs and policies, and provide for oversight, confirmation, and independent verification of those contractor programs.

The UMTRA ES\&H plan (DOE, 1992c) provides guidance and direction necessary for UMTRA contractors to implement their own ES\&H programs. The plan specifies the basic federal ES\&H standards and DOE requirements applicable to the program. The UMTRA PO, supported by the TAC, 
performs annual environmental audits of the RAC at each UMTRA Project construction site. These audits are documented and the findings are discussed with the RAC. All findings are tracked until they are resolved.

8. Prepare long-range environmental protection plans in accordance with guidance issued by the EH-1.

The UMTRA PO satisfies this long-range plan requirement by supporting the DOE ES\&H Management Plan, which supports the EM's 5-year budget submittal to Congress.

9. Ensure that budget requests provide for required environmental protection upgrades and corrective actions, that they are timely, and are consistent with pollution abatement plans prepared as required by OMB Circular A-106.

The UMTRA Project is not required to comply with the requirements of Office of Management and Budget (OMB) Circular A-106. According to DOE-HQ guidance on the FY1992 Circular A-106 plan update, DOE field offices are instructed to exclude activities at facilities not owned or leased by the DOE. The UMTRA Project is specifically listed as an example of activities not subject to reporting under OMB Circular A-106.

10. Prepare biannual pollution abatement plans required by OMB Circular A-106 and submit to the EH-1 on a schedule provided by that office.

Not applicable - see response to No. 9 .

11. Provide the EH-1 with all environmental information and documentation that is requested.

The Environmental Protection Division is the primary DOE-AL contact for environmental information and documentation requested by the EH-1. All DOE-HO requests are answered promptly.

12. Curtail or suspend any operation that poses a clear and present danger to a member of the public or to the environment.

Consistent with DOE-AL's Imminent Danger Response Actions policy (DOE, 1991c), the UMTRA PO has a standing policy that any UMTRA PO, RAC, or TAC employee has the authority to suspend operations if a clear and present danger to a worker, a member of the public, or the environment is identified. Stop-work authority on the UMTRA Project is identified in the UMTRA ES\&H plan (DOE, 1992c).

13. Provide for community public information and education programs concerning DOE environmental protection regulations and national security interests. 
The UMTRA Project provides a community relations plan and a public information repository at each of the remediation sites. These reports contain pertinent facts and information about the UMTRA Project and the site under construction. The UMTRA Project allows public participation in decision-making through the NEPA process and is responsive to all public inquiries made to the Project. Public meetings are conducted quarterly by the UMTRA PO to inform and involve the public on key issues being worked on at UMTRA Project sites.

\subsection{RESOURCE AND SCHEDULE SUMMARY}

Since the UMTRA Project is an environmental restoration project, most project resources are related to environmental protection. Therefore, the resources identified herein represent the cost estimates for all contractors and all work breakdown structure (WBS) codes. The schedule and cost estimates contained in Figures $1.8,1.9,1.10$, and 1.11 are planning estimates only. These figures give a broad overview of the resources and schedules included in the UMTRA Surface Project and Ground Water Project FY1996 field budgets. The UMTRA PO projects that the Surface Project will be completed in FY1998, with most remedial action completed 2 years earlier. Current estimates for the Ground Water Project are for a completion date in the year 2014. Estimates for both Surface and Ground Water Projects are revised, as necessary, to reflect Project changes. 


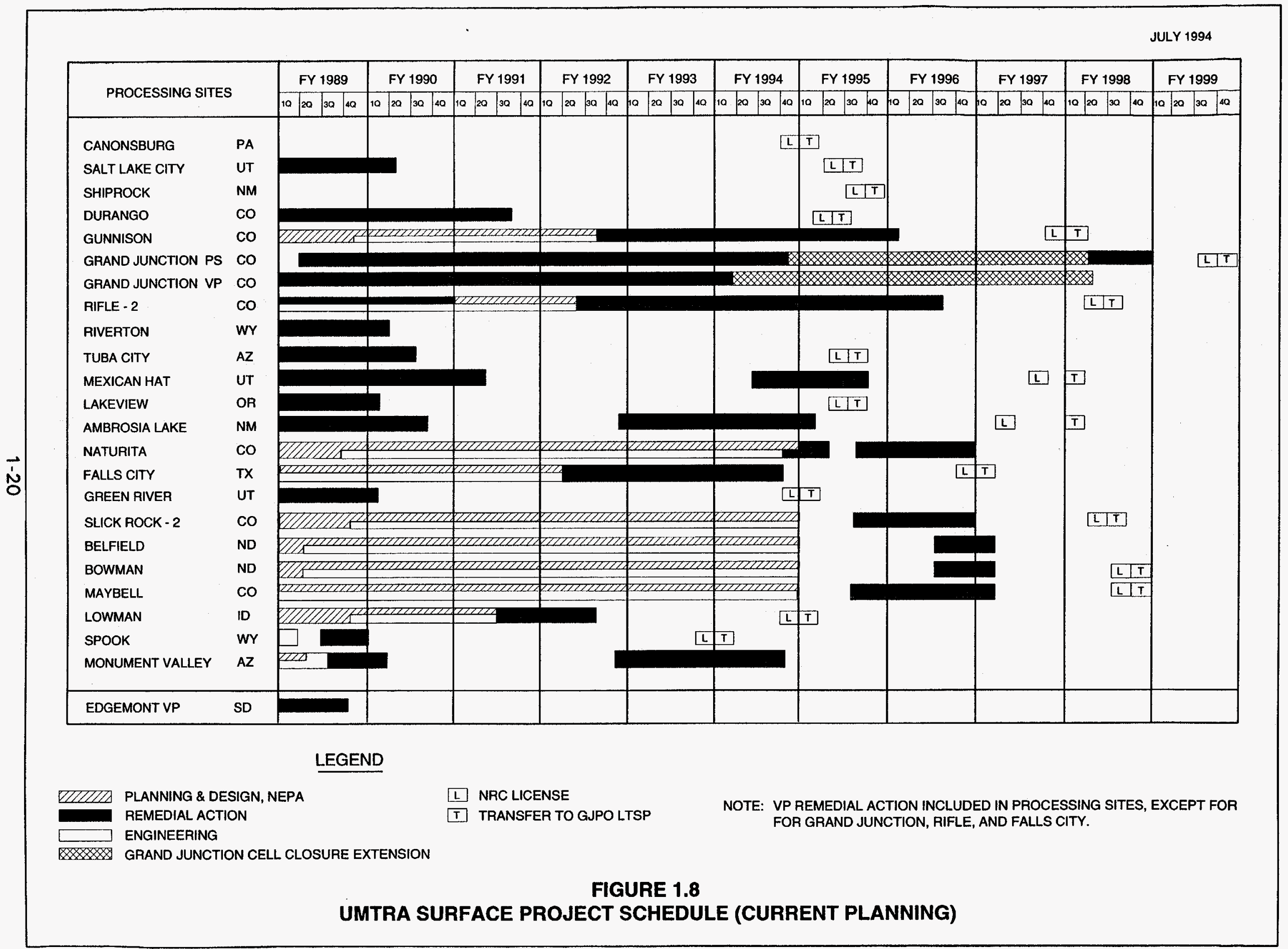




\begin{tabular}{||l|r|r|r|r|r|r||}
\hline \multicolumn{1}{|c|}{ SITE } & \multicolumn{1}{|c|}{ FY1995 } & \multicolumn{1}{|c|}{ FY1996 } & \multicolumn{1}{|c|}{ FY1997 } & FY1998 & FY1999 & \multicolumn{1}{c|}{ TOTAL } \\
\hline \hline AMBROSIA LAKE, NM & $\$ 2605.03$ & $\$ 408.50$ & $\$ 144.63$ & $\$ 15.45$ & $\$ 0.00$ & $\$ 3,173.61$ \\
\hline BELFIELD, ND & 109.29 & 22532.42 & 1264.37 & 376.06 & 0.00 & $24,282.14$ \\
\hline BOWMAN, ND & 36.58 & 568.64 & 641.14 & 275.14 & 0.00 & $1,521.50$ \\
\hline DURANGO, CO & 31.58 & 35.19 & 0.00 & 0.00 & 0.00 & 66.77 \\
\hline FALLS CITY, TX & 1632.37 & 210.31 & 47.37 & 38.92 & 0.00 & $1,928.97$ \\
\hline GRAND JUNCTION, CO & 23247.51 & 23435.30 & 26388.09 & 23578.22 & 6053.80 & $102,702.92$ \\
\hline GREEN RIVER, UT & -3.83 & 0.00 & 0.00 & 0.00 & 0.00 & .3 .83 \\
\hline GUNNISON, CO & 4537.04 & 1846.79 & 278.10 & 83.80 & 0.00 & $6,745.73$ \\
\hline LAKEVIEW, OR & 68.94 & 0.00 & 0.00 & 0.00 & 0.00 & 68.94 \\
\hline MAYBELL, CO & 13518.70 & 10754.10 & 4895.10 & 286.26 & 64.84 & $29,519.00$ \\
\hline MEXICAN HAT, UT & 3059.24 & 463.56 & 140.31 & 44.78 & 0.00 & $3,707.89$ \\
\hline MONUMENT VALLEY, AZ & 546.95 & 76.31 & 71.85 & 5.76 & 0.00 & 700.87 \\
\hline NATURITA, CO & 15941.16 & 8138.10 & 2540.43 & 230.88 & 0.00 & $26,850.57$ \\
\hline RIFLE, CO & 24147.14 & 6346.77 & 439.72 & 574.92 & 0.00 & $31,508.55$ \\
\hline RIVERTON, WY & 3.93 & 4.71 & 0.00 & 0.00 & 0.00 & 8.64 \\
\hline SALT LAKE CITY, UT & 580.69 & 20.62 & 0.00 & 0.00 & 0.00 & 601.31 \\
\hline SHIPROCK, NM & 80.64 & 9.78 & 0.00 & 0.00 & 0.00 & 90.42 \\
\hline SLICK ROCK, CO & 11967.54 & 10874.14 & 444.67 & 142.13 & 0.00 & $23,428.48$ \\
\hline TUBA CITY, AZ & 35.22 & 2.03 & 0.00 & 0.00 & 0.00 & 37.25 \\
\hline TOTAL & $102,145.72$ & $85,727.27$ & $37,295.78$ & $25,652.32$ & $6,118.64$ & $256,939.73$ \\
\hline
\end{tabular}

NOTE: MULTIPLY DOLLAR AMOUNTS BY 1000 FOR ACTUAL VALUES.

\author{
FIGURE 1.9 \\ ESTIMATED 5-YEAR COSTS FOR ALL WBS CODES FOR UMTRA SURFACE PROJECT \\ ESCALATED BASE AND CONTINGENCY
}




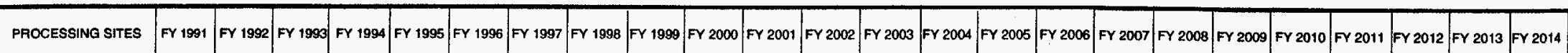

1. No Further Action Compliance Strategy Sites

1a. No Further Action Compliance Demonstration Approach

AMBROSIA LAKE NM \begin{tabular}{|l|l|l|l|l|}
\hline \\
\hline
\end{tabular}

BELFIELD

BOWMAN

CANONSBURG

MEXICAN HAT

SPOOK

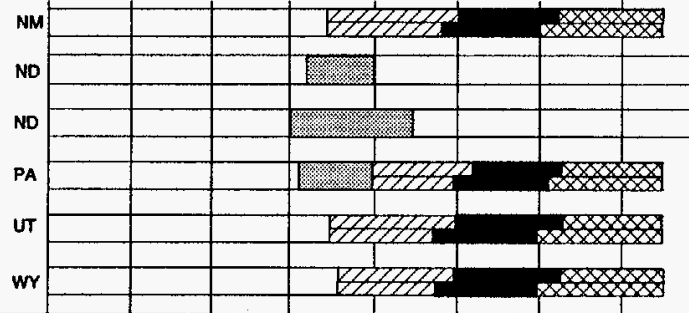

1. No Further Action Compliance Strategy Sites

1b. Demonstrated Compliance with Additional Characterization Approach

FALLS CITY

GREEN RIVER

LAKEVIEW

MAYBELL.

SALT LAKE CTY

SHIPROCK

TX

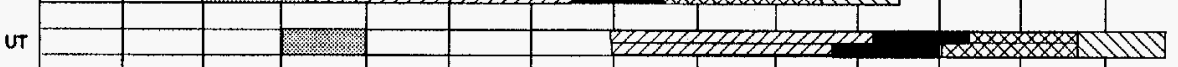

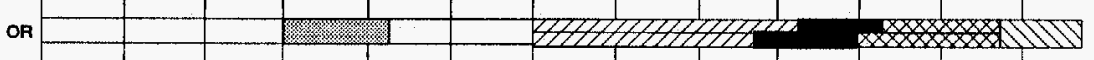

$\infty$\begin{tabular}{lllllll}
\hline & & & & & & \\
\hline
\end{tabular}

NM 1 II:

2. Passive Compliance Strategy Sites

DURANGO

-

GUNNISON

NATURITA

RIFLE

RIVERTON

III

SLLCK ROCK

3. Active Compliance Strategy Sites

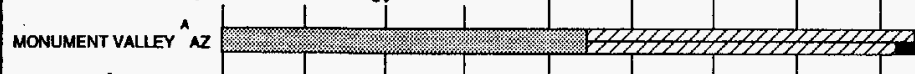

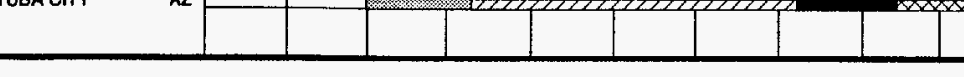

GW MONTOBING SITE CHAPACTERIZATION(SOWP)

A Front end of compllance strategy Implementation Includes a 1-year bld cycle.

B "Post Compliance" activity includes, where appropriate, Certification

Repor, Confirmation Report, LTSP Mod, and/or Hcensing.

For NFACD sites, this activity occurs immediately following the

For NFACO sites, this
pubilishing of the RAP.

FIGURE 1.10

UMTRA GROUND WATER PROJECT SITES SCHEDULE 


\begin{tabular}{|c|c|c|c|c|c|c|}
\hline SITE & FY1995 & FY1996 & FY1997 & FY1998 & FY1999 & TOTAL \\
\hline AMBROSIA LAKE, NM & $\$ 134,04$ & $\$ 0.00$ & $\$ 0.00$ & $\$ 0.00$ & $\$ 0.00$ & $\$ 134.04$ \\
\hline BELFIELD, ND & 148.47 & 279.14 & 212.96 & 274.30 & 196.05 & 1.110 .92 \\
\hline BOWMAN. ND & 149.24 & 0.00 & 0.00 & 0.00 & 196.05 & 345.29 \\
\hline CANNONSBURG, PA & 194.92 & 301.25 & 229.44 & 292.81 & 211.24 & 1.229 .66 \\
\hline DURANGO, CO & 184.50 & 297.16 & 259.47 & 305.44 & 1180.89 & 2.227 .46 \\
\hline FALLS CITY, TX & 1194.07 & 318.89 & 3226.08 & 1809.37 & 1071.16 & $7,619.57$ \\
\hline GRAND JUNCTION, CO & 137.80 & 343.58 & 260.91 & 1031.72 & 1230.38 & $3,004.39$ \\
\hline GREEN AIVER, UT & 121.15 & 0.00 & 261.89 & 329.28 & 241.21 & 953.53 \\
\hline GUNNISON, CO & 167.99 & 360.35 & 1075.84 & 562.39 & 2071.16 & 4.237 .73 \\
\hline LAKEVIEW, OR & 167.70 & 270.66 & 206.66 & 267.20 & 190.24 & 1.102 .46 \\
\hline LOWMAN, 10 & 118.50 & 0.00 & 0.00 & 0.00 & 0.00 & 118.50 \\
\hline MAYBELL, CO & 359.04 & 16.13 & 0.00 & 0.00 & 352.26 & 727.43 \\
\hline MEXICAN HAT, UT & 118.50 & 161.03 & 166.74 & 0.00 & 59.60 & 505.87 \\
\hline MONUMENT VALLEY, AZ & 219.34 & 1198.51 & 711.44 & 3872.08 & 4237.08 & $10,238.45$ \\
\hline NATURITA, CO & 271.18 & 308.37 & 235.06 & 299.13 & 342.01 & $1,455.75$ \\
\hline RIFLE，CO & 254.68 & 266.70 & 348.04 & 1789.27 & 2485.32 & $5,144.01$ \\
\hline RIVERTON, WY & 620.65 & 1345.72 & 701.31 & 1315.82 & 3099.91 & 7.083 .41 \\
\hline SALT LAKE CITY, UT & 184.01 & 293.30 & 214.23 & 275.72 & 197.21 & 1.164 .47 \\
\hline SHIPROCK, NM & 1018.36 & 742.19 & 766.54 & 381.86 & 54.69 & $2,963.64$ \\
\hline SLICK ROCK, CO & 242.37 & 355.93 & 270.08 & 338.47 & 793.96 & $2,000.81$ \\
\hline SPOOK; WY & 128.86 & 0.00 & 0.00 & 0.00 & 0.00 & 128.86 \\
\hline TUBA CITY, AZ & 876.17 & 943.68 & 3091.67 & 4898.88 & 6638.85 & $16,449.25$ \\
\hline TOTAL & 7.011 .54 & $7,802.59$ & 12.238 .36 & $18,043.74$ & $24,849.27$ & $69,945.50$ \\
\hline
\end{tabular}

NOTE: MULTIPLY DOLLAR AMOUNTS BY 1000 FOR ACTUAL VALUES.

FIGURE 1.11

ESTIMATED 5-YEAR COSTS FOR ALL WBS CODES FOR UMTRA GROUND WATER PROJECT ESCALATED BASE AND CONTINGENCY 


\subsection{NOTIFICATIONS}

Requirements for the reporting of occurrences (emergencies, unusual occurrences, and off-normal occurrences) are specified in DOE Order 5000.3B. The UMTRA Project is considered to be a single facility for the purposes of this order. An UMTRA Project Occurrence Reporting and Processing System (ORPS) Program and implementing procedures have been developed to ensure compliance with the order (DOE, 1993c). In the implementing procedures, the UMTRA Project Manager is identified as the DOE facility representative, UMTRA PO line management staff have been identified as DOE facility representative designees, and the UMTRA PO site managers have been identified as the facility managers for UMTRA sites. Occurrence notification of DOE-HO and DOE-AL are addressed in the program, as well as U.S. Department of Transportation (DOT) notification procedures for spills of hazardous wastes, including notification of the National Response Center. The UMTRA PO continues to participate in the DOE-AL Daily Incident and Occurrence Reporting System.

The RAC and the TAC have developed emergency notification plans and procedures to satisfy the requirements of DOE Order 5000.3B. Both contractors have designated DOE Order 5000.3B ORPS program coordinators responsible for maintaining the program.

For all DOE Order 5000.3B occurrence categories, reporting to the responsible UMTRA Project contractor office is required. The contractor office then has the responsibility to report to the UMTRA PO. Depending on the type of occurrence, the contractor office will report to state and federal agencies having appropriate jurisdiction as delineated in permits and regulatory requirements. Additional reporting requirements are then determined by the UMTRA PO. Reportable environmental incidents are electronically submitted by the UMTRA PO to the DOE database as required by DOE Order $5000.3 \mathrm{~B}$.

The RAC and the TAC are required to notify the UMTRA PO in case of a reportable occurrence. These procedures include reports related to radiological releases or spills. Section XI, Emergency Action, in the RAC's Construction Environment, Safety and Health Management Plan (RAC, 1994a), covers severe weather, contaminated material spilled in transit, and evacuation from the work site. At each active UMTRA Project site, a list is posted with emergency telephone numbers and local utility numbers.

The RAC developed a procedure to direct the emergency response to transportation accidents involving mill tailings and a health physics emergency response procedure that details the notification requirements for accidents involving radioactive mill tailings. These emergency response procedures are in compliance with the notification requirements of DOT Exemption DOT-E 10594 and applicable portions of 49 CFR Parts 171, 172, and 173.

The UMTRA PO also complies with reporting requirements for the National Pollutant Discharge Elimination System (NPDES) established by the Clean Water Act (33 USC \$1251 et seq.) and the Emergency Planning and Community Right-to-Know Act of 1986 (42 USC $\$ 11001$ et seq.). 
The TAC and the RAC are responsible for jointly preparing an annual site environmental report, that includes a summary of occurrences and exceedances. It is reviewed and distributed through the UMTRA PO (see Section 3.2).

DOE Order 5400.5 states that the public dose limit from exposure to radiation sources from routine DOE operations and activities (including remedial action) is 100 millirem (mrem) annual effective dose equivalent. Additionally, this Order states (to the extent required by the Clean Air Act, 42 USC $\$ 7401$ et seq.) that the exposure of members of the public to radioactive materials released to the atmosphere as a consequence of routine DOE activities shall not cause members of the public to receive $10 \mathrm{mrem}$ annual effective dose equivalent. However, conditions exist, and will continue to occur, during the UMTRA Project remedial activities where the public could be exposed to a dose in excess of 100 mrem per year (Oldham, 1990; Themelis, 1990). The conditions producing radon-222 emanation during remedial action are beyond the RAC's control. However, it is the intent of the UMTRA PO that when remedial action at a site is completed (tailings stabilized), the site will meet applicable requirements of DOE Order 5400.5. Therefore, the projected doses to the public from remedial action activities (which have been previously calculated in the respective site environmental impact statement or environmental assessment) are not repeated annually. The PO and DOE-AL are working with DOE-HO to resolve the applicability of DOE Order 5400.5 . 


\subsection{PLANNING AND REPORTING}

This section describes the series of plans and reports that the UMTRA Project is required to prepare to fulfill the requirements of DOE Order 5400.1 as part of its environmental protection program. These requirements include a long-range environmental protection plan, an annual environmental site report, and an OMB Circular A-106 report. The TAC and the RAC are responsible for the preparation of the Project documents, which are subject to review and approval by the UMTRA PO, that satisfy the DOE Order 5400.1 requirements.

\subsection{LONG-RANGE ENVIRONMENTAL PROTECTION PLAN}

This long-range planning requirement is now met by supporting the DOE-HO ES\&H Management, which supports the EM's 5-year budget submittal to Congress. The UMTRA PO provides UMTRA-specific information for inclusion in the ES\&H Management Plan, including major milestones, funding requirements, Project assessments, history, and activity data sheets for each UMTRA Project site. The RAC and the TAC support the UMTRA PO in the annual preparation of the UMTRA Project impact for the ES\&H Management Plan.

\subsection{ANNUAL SITE ENVIRONMENTAL REPORT}

The Project is in compliance with the DOE Order 5400.1 requirement for the preparation of an annual site environmental report. The UMTRA PO prepares an UMTRA Project annual environmental report, which includes information on all UMTRA Project sites that have conducted significant environmental remediation programs. Summary reports of the NEPA-related compliance activities performed by the TAC are also included, as are construction-related compliance activities performed by the RAC. The TAC is responsible for performing water quality analysis from the ground water monitor wells established at each site. These data are also incorporated into the annual report. The report also serves as a vehicle to report occurrences and exceedances.

All field-gathered environmental data related to remedial action, except passive radon data, are summarized and presented graphically to assess site environmental management performance. These data are reviewed internally by appropriate RAC and TAC managers and relayed to each site with management's evaluations. Significant trends are investigated and corrective action is taken as necessary.

The annual environmental report, covering the various activities of the previous calendar year, is prepared and distributed each year. Funding for the report is provided through general site and coordination budgets. The UMTRA PO is responsible for approving and distributing the report to the DOE-AL, the DOE-HQ, and the states and Indian tribes. 


\subsection{OMB CIRCULAR A-106}

The UMTRA Project is exempted from compliance with the annual reporting requirements of OMB Circular A-106. According to DOE guidance on the FY1992 Circular A-106 plan update, DOE field offices are instructed to exclude activities at facilities not owned or leased by the DOE. The UMTRA Project is specifically listed as an example of activities not subject to reporting under OMB Circular A-106. 


\subsection{SPECIAL PROGRAMS}

This section describes the special programs the UMTRA Project has developed as part of its environmental protection program to fulfill the requirements of DOE Order 5400.1 for a ground water protection management program, a waste minimization program, and a pollution prevention awareness program. The UMTRA PO has chosen to incorporate into one planning document both the waste minimization and the pollution prevention awareness programs. The UMTRA Project has also instituted an ES\&H regulatory operating envelope program to document compliance of its environmental programs. The TAC and the RAC are responsible for the preparation of the special program plan documents, subject to review and approval by the UMTRA PO.

\subsection{GROUND WATER PROTECTION MANAGEMENT PROGRAM}

The UMTRA Project is mandated by the UMTRCA to minimize health hazards to the public and the environment. The EPA has proposed ground water protection standards (52 FR 36000 (1987)) specifically for the UMTRA Project. The final rule is currently under review by the Office of Management and Budget. In addition, the NRC is responsible for providing regulatory oversight of the UMTRA Project, including the ground water protection program. Since the UMTRA Project is an environmental remediation project, the primary concerns for ground water protection arise from the selected remedial action alternatives and from residual contamination after the surface remedial action is complete. Ground water protection is considered in evaluating remedial action alternatives and general site activities.

The DOE has invested significant resources to address ground water protection on the UMTRA Project. An integral part of UMTRA is an experienced staff of hydrogeologists, geochemists, regulatory analysts, engineers, QA specialists, and data managers who provide a strong technical basis for the development of the surface and ground water remediation programs. Over the life of the Project, a substantial body of hydrogeologic data has been collected. A large quality-assured computer database is used to store hydrogeologic data. Also, state-of-the-art computer models are used in conjunction with the hydrogeologic data to develop ground water protection strategies and assess and remediate risk to the public and the environment.

The UMTRA Project ground water protection program has been developed and implemented by the TAC and the RAC for the DOE. The UMTRA Project Groundwater Protection Management Program Plan (DOE, 1993d) summarizes the remedial action status of the 24 UMTRA Project sites. The plan addresses the types of information required to develop a site-specific water resources protection strategy for each site. In addition, the plan identifies and describes available Project technical and site-specific documents that provide guidance for the ground water protection program.

This plan also describes applicable environmental protection laws, regulations, executive orders, and internal DOE policies that pertain to the preservation and 
protection of ground water resources at UMTRA Project sites. Finally, it highlights the Project programs for surface remedial action, long-term surveillance, and ground water monitoring and restoration activities for the preservation and protection of ground water resources at each of the sites.

The UMTRA Project Groundwater Protection Management Program Plan (DOE, 1993d) is reviewed annually and updated every 3 years.

\subsection{WASTE MINIMIZATION/POLLUTION PREVENTION AWARENESS PROGRAM}

The UMTRA Project is mandated to remediate designated inactive uranium tailings sites and associated wastes by consolidating and stabilizing the RRMs in geotechnically suitable impoundments. As an environmental restoration program, the Project does not have manufacturing or production facilities, nor does it routinely generate new hazardous waste streams.

A combined Waste Minimization/Pollution Prevention Awareness Program (WM/PPAP) plan, for both office/administrative locations and construction and site activities, has been developed and was implemented in FY1992. The WM/PPAP plan (DOE, 1994b), which was revised in FY1994, will be reviewed annually and updated every 3 years.

The WM/PPAP plan is intended to satisfy DOE requirements for the management of radioactive and hazardous wastes mandated by DOE Orders 5400.1 and 5820.2A. As stated above, long-term volume-specific comprehensive goals for waste minimization, such as those specified by the Resource Conservation and Recovery Act (42 USC $\$ 6901$ et seq.), are not appropriate for nonoperational facilities such as the UMTRA Project. It is more appropriate to adopt as an overall goal the as low as reasonably achievable (ALARA) concept routinely associated with personnel exposures.

The WM/PPAP plan addresses UMTRA Project requirements for source reduction, minimization, and pollution abatement. It serves as a guidance document for current and future waste minimization and pollution prevention activities by specifying responsibilities, goals, and key elements of the joint program. These goals are:

1. Eliminate the generation of hazardous waste.

2. Reduce the generation of radioactive waste to ALARA.

3. Reduce the generation of nonhazardous solid waste to ALARA.

4. Use the ES\&H Committee to address waste minimization and pollution prevention issues, as needed.

5. Provide guidance for management and worker awareness in waste minimization and pollution prevention. 
6. Provide guidance for the development of site-specific plans that implement waste minimization and pollution prevention practices.

Waste minimization involves activities that will eliminate or minimize the generation of radioactive, hazardous, and other solid wastes. For the UMTRA Project, waste minimization begins with the development and implementation of subcontract specifications and the RAC construction ES\&H plan (RAC, 1994a) and the RAC waste minimization plan (RAC, 1992). These documents outline specific waste minimization requirements that must be developed by subcontractors and approved by Project management.

During the startup of construction activities at new sites, or during recent construction at active sites, site-specific plans are developed to detail the necessary waste management activities that ensure all elements of the WM/PPAP plan are implemented.

\subsection{ES\&H OPERATING ENVELOPE PROGRAM}

The UMTRA PO has established an ES\&H regulatory operating envelope program to identify all environmental regulations applicable to the UMTRA Project and determine the level of compliance. This program is consistent with the Standards/Requirements Program being developed by DOE-HO and will improve the UMTRA PO's ability to assess its environmental programs.

The Project has created a regulatory operating envelope database, identified the applicable regulatory documents, and developed justifications for nonapplicable regulations. The UMTRA PO also has developed a plan to implement the next stage of the program, which involves determining the applicability of individual regulatory criteria, assessing compliance, and identifying actions necessary to attain compliance (DOE, 1993e). This plan describes the Project's systematic approach for defining its regulatory operating envelope and documenting its compliance status. The TAC is responsible for implementing the program and maintaining the operating envelope database. 


\subsection{ENVIRONMENTAL MONITORING PROGRAMS}

\subsection{ENVIRONMENTAL MONITORING PLANS}

The UMTRA Project Environmental Monitoring Plan (EMP) defines responsibilities and provides guidance on the format and content of the various subtier environmental monitoring plans for the UMTRA Project sites (DOE, 1992d). The EMP includes a description of all Project environmental monitoring programs. The relation of the EMP and its subtier plans to the environmental protection program is shown in Figure 1.3. The EMP contains the requirements for the environmental monitoring program concerning 1) the measurement and monitoring of effluents, and 2) surveillance through the measurement, monitoring, and calculation of the effects of the Project's operations on the environment and public health. The objectives of the program are to demonstrate compliance to applicable regulations, confirm adherence to DOE environmental policies, and support environmental management decisions. A critical element of the monitoring program is QA and data verification.

Environmental monitoring for ground water and radon, the areas of primary focus of the UMTRA environmental monitoring program, are also described in Guidance for Implementing the UMTRA Project Long-Term Surveillance Program (DOE, 1992e), the "Ground Water Monitoring Plan" (an attachment to the EMP) and the Outdoor Radon Monitoring Plan for the UMTRA Project Sites (DOE, 1990). QA and data verification procedures and requirements are discussed in the UMTRA Project Quality Assurance Program Plan (QAPP) (DOE, 1994c).

\subsection{ENVIRONMENTAL MONITORING ACTIVITIES}

The project monitoring program is divided into two general categories: 1) environmental surveillance and 2) effluent monitoring. Radiological surveillance is conducted at Project sites to ensure that radionuclide releases are within the limits of DOE Order 5400.5, with the exception of radon gas levels, before and during construction activities. Radon releases from unremediated tailings piles are beyond the control of the Project. Monitoring is performed in air for radon and radioactive particulates, in surface water for dissolved and suspended radionuclides, and for direct gamma radiation. These measurements are compared to background levels established during pre-remedial action surveys and to applicable regulatory limits.

Environmental surveillance is conducted for nonradiological pollutants, including measuring total suspended particulates in air at all Colorado sites, and monitoring discharge of water as required by the Clean Water Act at all sites. Ground water monitoring is conducted at all sites prior to remedial action to characterize hydrological and contaminant conditions. Ground water is monitored during remedial action to determine the remedial action effects, and after remedial action where necessary to demonstrate compliance with the proposed EPA ground water protection standards. 
The TAC conducts pre-remedial action monitoring and characterization for ground water and radon. The Outdoor Radon Monitoring Plan for the UMTRA Project Sites (DOE, 1990) details radon measurement techniques and monitoring requirements during all phases of remediation. Ground water monitoring is conducted in accordance with the "Ground Water Monitoring Plan" attachment to the EMP. Initial site-specific monitoring requirements are developed based on preoperational site characterization. Water sampling and analysis plans are prepared for each site and revised annually based on reviews of ground water quality data.

Ambient air quality monitoring is performed by the RAC during construction as required by the applicable federal, state, or local air quality permits. Ambient air quality monitoring at the UMTRA Project sites ranges from estimating fugitive dust levels using opacity criteria to measuring total suspended particulates as required by 40 CFR Part 50 and as detailed in the EMP. The aspects of the program coordinated with state regulatory officials include siting monitoring stations, developing monitoring protocols, conducting audits, acquiring meteorological information, and evaluating current site and background data.

Either an NPDES permit or the equivalent state permit is obtained before remedial action is started at each UMTRA Project site. Data gathered for the site-specific NEPA document and RAP are used to provide the water quantity and quality data required to complete the water use and discharge permit application. In general, shallow ground water data are used to estimate the quality of the water to be collected. Historical meteorological data are used to determine the quantity of water that may accumulate at the site. If it appears that there will be a net positive accumulation of water, an appropriate water treatment and discharge plan is required.

The permits will specify site-specific limitations on both the volume and contaminant levels in water to be discharged. In addition, the permit will state the frequency with which these measurements are to be made and the form in which they must be reported.

RAC site engineering personnel are assigned the task of collecting the data required by the individual permit and reporting it to the governing authority. The RAC site engineering, safety, and industrial hygiene personnel are assigned the responsibility of ensuring that all permit requirements are completed.

Attachment A briefly describes the environmental monitoring at Project sites with ongoing surface remedial action activities.

The estimated FY1995 cost of the UMTRA Project environmental monitoring activities at all UMTRA Project sites is $\$ 2.25$ million. 


\subsection{QUALITY ASSURANCE AND DATA VERIFICATION}

6.1

\section{QUALITY ASSURANCE PROGRAM}

The UMTRA Project QA program (DOE, 1994c) is currently consistent with DOE Order $5700.6 \mathrm{C}$ and $10 \mathrm{CFR} \$ 830.120$ and covers the applicable portions of the 11 elements described in DOE Order 5400.1. The TAC's QAPP (TAC, 1994) uses the Project QAPP for guidance and instruction in QA and quality control activities. A statement of policy regarding the RAC's QAPP (RAC, 1994b) has been provided to DOE. Both the RAC and the TAC revised their QAPPs in FY1994 to conform with 10 CFR $\$ 830.120$.

In addition, independent data verification is performed by the TAC and the RAC. The TAC, in conjunction with the UMTRA PO, performs QA in-process surveillances, environmental audits, and radiological surveillances at least annually at all operating UMTRA Project sites. Prequalification QA audits are conducted prior to awarding subcontracts to analytical laboratories. Thereafter, annual $Q A$ audits are conducted to verify compliance with subcontract technical and $\mathrm{QA}$ requirements. All environmental data, methodology of collection, and analyses performed are reviewed for adequacy, accuracy, and completeness. Reports are then generated requiring RAC response, as necessary, for audits and surveillances conducted at UMTRA Project sites during remedial action. Reports of QA audits of subcontract laboratories are generated and may also require a written response and corrective action. Periodic audits and surveillance are conducted as the Project progresses. The RAC has established an environmental assessment program in conjunction with the quality audit program referenced in the RAC QAPP.

\subsection{LABORATORY CERTIFICATION}

The laboratories in Table 6.1 have been or are currently used by the TAC and the RAC for environmental analyses.

The radiological analyses laboratories used by the RAC and the TAC participate in the EPA's Environmental Monitoring Systems Laboratory Las Vegas Intercomparison Studies Program, as required by DOE Order 5400.1. Quarterly summaries of their Intercomparison Studies performance are sent by the laboratories to the RAC and the TAC for review by data management and $Q A$ staff.

In addition, independent quarterly performance evaluation samples are sent by the TAC to the participating laboratories. These samples are prepared for the UMTRA Project by RUST Geotech and cover constituents of interest to the UMTRA Project. 
Table 6.1 UMTRA Project contract laboratories

\begin{tabular}{lcc}
\hline \multicolumn{1}{c}{ Laboratory } & TAC & RAC \\
\hline Accu-Labs Research & - & $\mathrm{X}$ \\
ACZ Laboratories, Inc. & $\mathrm{X}$ & - \\
Barringer Laboratories, Inc. & $\mathrm{X}$ & $\mathrm{X}$ \\
CDS Laboratories & - & $\mathrm{X}$ \\
Core Laboratories, Inc. & $\mathrm{X}$ & - \\
Data Chem Laboratories, Inc. & - & $\mathrm{X}$ \\
Environmental Science and Engineering, Inc. & $\mathrm{X}$ & - \\
IEA Laboratory & $\mathrm{X}$ & - \\
IT Analytical Services & $\mathrm{X}$ & - \\
Lockheed Analytical Laboratory & $\mathrm{X}$ & - \\
R. F. Weston Analytical Laboratory & $\mathrm{X}$ & - \\
RUST Geotech & $\mathrm{X}$ & $\mathrm{X}$ \\
Savannah Laboratories & $\mathrm{X}$ & - \\
Tech/Ops Landauer, Inc. & - & $\mathrm{X}$ \\
TMA/Eberline Analytical, Inc. & - & $\mathrm{X}$ \\
Weyerhauser Laboratories, Inc. & $\mathrm{X}$ & - \\
\hline
\end{tabular}

Tech/Ops Landauer, Inc., which is used for radon monitoring services, participates in the DOE's Technical Measurement Center Program.

CDS Laboratories, which is the primary vendor for total suspended particulate analysis, participates in the EPA Interlaboratory Correlation Total Suspended Particulate Audit Program.

In addition to the QA program mentioned above, the RAC and the TAC periodically ship blank samples to the laboratories for analyses as a quality control check of the data, and to ensure that the required monitoring sensitivities are being achieved. The RAC and the TAC also perform initial and periodic follow-up audits of analytical laboratories.

These QA checks of analytical laboratories have been determined to be adequate and appropriate for UMTRA Project environmental analyses.

\subsection{DOE LABORATORY OA PROGRAM FOR RADIOACTIVE MATERIAL}

UMTRA Project sites have on-site laboratories to analyze soil samples for radium-226 activity concentration and airborne particulates for gross alpha particle activity concentration. The RAC measures the radium-226 activity 
concentration in soil samples with an sodium iodide opposed-crystal system. The system is calibrated with radium-226 standards obtained from the DOE's Technical Measurement Center in Grand Junction, Colorado.

The TAC provides blind soil samples (spiked with radium-226) to the RAC for radium-226 analysis. These blind soil samples are used by the TAC to test sample result accuracy and quality control. The RAC's blind test results must meet test criteria presented in the UMTRA Project Technical Approach Document (DOE, 1989).

The UMTRA Project does not participate in the DOE Laboratory Quality Assurance Program because the program's test matrices predominantly contain fission products and transuranium elements, while the UMTRA Project's focus is on naturally occurring radioactivity and radionuclides.

\subsection{INDEPENDENT DATA VERIFICATION}

The DOE QA manager has the responsibility for overseeing development of the Independent Data Verification Program. The present data collection, analysis, and review programs now in place meet the requirements and intent of the data verification section of DOE Order 5400.1. Environmental data verification is discussed in the EMP (DOE, 1992d). 


\subsection{REFERENCES}

DOE (U.S. Department of Energy), 1994a. GJPO Environmental Protection Implementation Plan, prepared by the U.S. Department of Energy, Grand Junction Projects Office, Grand Junction, Colorado.

DOE (U.S. Department of Energy), 1994b. Uranium Mill Tailings Remedial Action Project Waste Minimization and Pollution Prevention Awareness Program Plan, DOE/AL/62350-144, prepared by the U.S. Department of Energy, UMTRA Project Office, Albuquerque Operations Office, Albuquerque, New Mexico.

DOE (U.S. Department of Energy), 1994c. UMTRA Project Quality Assurance Program Plan, DOE/AL/62350-72D, prepared by the U.S. Department of Energy, UMTRA Project Office, Albuquerque Operations Office, Albuquerque, New Mexico.

DOE (U.S. Department of Energy), 1993a. Environmental Management Audit: Uranium Mill Tailings Remedial Action Project, prepared by the U.S. Department of Energy, Office of Environmental Audit, Washington, D.C.

DOE (U.S. Department of Energy), 1993b. Uranium Mill Tailings Remedial Action Project Environmental Line Management Audit Action Plan, prepared by the U.S. Department of Energy, UMTRA Project Office, Albuquerque Operations Office, Albuquerque, New Mexico.

DOE (U.S. Department of Energy), 1993c. UMTRA Project Implementing Procedures for DOE Order 5000.3B, Occurrence Reporting and Processing of Operations Information, prepared by the U.S. Department of Energy, UMTRA Project Office, Albuquerque Operations Office, Albuquerque, New Mexico.

DOE (U.S. Department of Energy), 1993d. Groundwater Protection Management Program Plan, DOE/AL/62350-92, prepared by the U.S. Department of Energy, UMTRA Project Office, Albuquerque Operations Office, Albuquerque, New Mexico.

DOE (U.S. Department of Energy), 1993e. Environmental, Safety, and Health Regulatory Implementation Plan, DOE/AL/62350-44, prepared by the U.S. Department of Energy, UMTRA Project Office, Albuquerque Operations Office, Albuquerque, New Mexico.

DOE (U.S. Department of Energy), 1992a. Albuquerque Operations Office Environmental Policy Statement, October 1992, prepared by the U.S. Department of Energy, UMTRA Project Office, Albuquerque Operations Office, Albuquerque, New Mexico.

DOE (U.S. Department of Energy), 1992b. UMTRA Project Environmental, Safety, and Health Goal Statement, May 1992, prepared by the U.S. Department of Energy, UMTRA Project Office, Albuquerque Operations Office, Albuquerque, New Mexico. 
DOE (U.S. Department of Energy), 1992c. UMTRA Project Environmental, Safety, and Health Plan, UMTRA-DOE/AL/150224.0006, prepared by U.S. Department of Energy, UMTRA Project Office, Albuquerque Operations Office, Albuquerque, New Mexico.

DOE (U.S. Department of Energy), 1992d. UMTRA Project Environmental Monitoring Plan, UMTRA-DOE/AL/150129.0000, prepared by the U.S. Department of Energy, UMTRA Project Office, Albuquerque Operations Office, Albuquerque, New Mexico.

DOE (U.S. Department of Energy), 1992e. Guidance for Implementing the UMTRA Project Long-Term Surveillance Program, UMTRA-DOE/AL/350124.0001 Rev. A, prepared by the U.S. Department of Energy, UMTRA Project Office, Albuquerque Operations Office, Albuquerque, New Mexico.

DOE (U.S. Department of Energy), 1991a. Environmental Audit: Rifle, Gunnison and Grand Junction UMTRA Project Sites, prepared by the U.S. Department of Energy, Office of Environmental Audit, Washington, D.C.

DOE (U.S. Department of Energy), 1991b. Final Action Plan in Response to the Environmental Audit of the Uranium Mill Tailings Remedial Action Project at the Grand Junction, Gunnison, and Rifle, Colorado, Sites, prepared by the U.S. Department of Energy, UMTRA Project Office, Albuquerque Operations Office, Albuquerque, New Mexico.

DOE (U.S. Department of Energy), 1991c. DOE Albuquerque Operations Imminent Danger Response Actions, Announcement OOM No. 47, 19 September 1991, prepared by the U.S. Department of Energy, UMTRA Project Office, Albuquerque Operations Office, Albuquerque, New Mexico.

DOE (U.S. Department of Energy), 1990. Outdoor Radon Monitoring Plan for the UMTRA Project Sites, UMTRA-DOE/AL/150225.0000, prepared by the U.S. Department of Energy, UMTRA Project Office, Albuquerque Operations Office, Albuquerque, New Mexico.

DOE (U.S. Department of Energy), 1989. Technical Approach Document, UMTRA-DOE/AL/050425.0002, prepared by the U.S. Department of Energy, UMTRA Project Office, Albuquerque Operations Office, Albuquerque, New Mexico.

Oldham, J. G., 1990. Project Director, MK-Ferguson Company, letter 90-3050-236 to M. L. Matthews, Project Manager, U.S. Department of Energy, UMTRA Project, dated 2 April 1990.

RAC (Remedial Action Contractor), 1994a. Construction Environment, Safety and Health Management Plan, MKF-UMTRA-4, prepared by MK-Ferguson Company, Albuquerque, New Mexico, for the U.S. Department of Energy, UMTRA Project Office, Albuquerque Operations Office, Albuquerque, New Mexico. 
RAC (Remedial Action Contractor), 1994b. Quality Assurance Program Plan, MKFUMTRA-5, prepared by MK-Ferguson Company, Albuquerque, New Mexico, for the U.S. Department of Energy, UMTRA Project Office, Albuquerque Operations Office, Albuquerque, New Mexico.

RAC (Remedial Action Contractor), 1992. Waste Minimization and Pollution Prevention Program for the UMTRA Project, prepared by MK-Ferguson Company, Albuquerque, New Mexico, for the U.S. Department of Energy, UMTRA Project Office, Albuquerque Operations Office, Albuquerque, New Mexico.

TAC (Technical Assistance Contractor), 1994. UMTRA Technical Assistance Contractor Quality Assurance Program Plan, DOE/AL/62350-56, REV. 5, October 1994, prepared by Jacobs Engineering Group Inc., Albuquerque, New Mexico, for the U.S. Department of Energy, UMTRA Project Office, Albuquerque Operations Office, Albuquerque, New Mexico.

Themelis, J. G., 1990. U.S. Department of Energy, letter to J. E. Dickhoner, U.S. Department of Energy (EH-32), dated 16 May 1990.

\section{CODE OF FEDERAL REGULATIONS}

10 CFR Part 40, Domestic Licensing of Source Material, U.S. Nuclear Regulatory Commission (1994).

10 CFR Part 830, Nuclear Safety Management, U.S. Department of Energy (1994).

10 CFR Part 1021, Compliance with the National Environmental Policy Act, U.S. Department of Energy (1994).

40 CFR Part 50, National Primary and Secondary Ambient Air Quality Standards, U.S. Environmental Protection Agency (1994).

40 CFR Part 192, Health and Environmental Protection Standards for Uranium and Thorium Mill Tailings, U.S. Environmental Protection Agency (1994).

49 CFR Part 171, Hazardous Material Information, Regulations, and Definitions, U.S. Department of Transportation (1994).

49 CFR Part 172, Hazardous Material Tables and Communications Regulations, U.S. Department of Transportation (1994).

49 CFR Part 173, Hazardous Material Shippers General Requirements, U.S. Department of Transportation (1994). 


\section{DOE ORDERS}

Order 5000.3B, Occurrence Reporting and Processing of Operations Information, 19 January 1993, U.S. Department of Energy, Washington, D.C.

Order 5400.1, General Environmental Protection Program, 8 November 1988, U.S. Department of Energy, Washington, D.C.

Order 5400.2A, Environmental Compliance Issue Coordination, January 1989, U.S. Department of Energy, Washington, D.C.

Order 5400.5, Radiation Protection of the Public and the Environment, February 1990, U.S. Department of Energy, Washington, D.C.

Order 5482.1B, Environmental, Safety and Health Appraisal Program, September 1986, U.S. Department of Energy, Washington, D.C.

Order 5700.6C, Quality Assurance, 21 August 1991, U.S. Department of Energy, Washington, D.C.

Order 5820.2A, Radioactive Waste Management, 26 September 1988, U.S. Department of Energy, Washington, D.C.

\section{FEDERAL REGISTER}

52 FR 36000. Standards for Remedial Actions at Inactive Uranium Processing Sites;

Proposed Rule, 24 September 1987.

\section{UNITED STATES CODE}

33 USC \$1251 et seq., Clean Water Act, 27 December 1977.

42 USC $\$ 4321$ et seq., National Environmental Policy Act, 1 January 1970.

42 USC $\$ 6901$ et seq., Resource Conservation and Recovery Act, 21 October 1976.

42 USC $\$ 7401$ et seq., Clean Air Act, 17 December 1963.

42 USC $\$ 7922$ et seq., Uranium Mill Tailings Radiation Control Act, 8 November 1978.

42 USC $\$ 11001$ et seq., Emergency Planning and Community Right-to-Know Act, 17 October 1986. 
ATTACHMENT A

ENVIRONMENTAL PROTECTION AT SURFACE REMEDIAL ACTIONS SITES 


\section{ATTACHMENT A}

\section{Environmental Protection at Surface Remedial Action Sites}

Of the 24 designated Uranium Mill Tailings Remedial Action (UMTRA) Project sites, surface remedial action is underway at only 5 locations at the beginning of fiscal year 1995: Grand Junction, Colorado (vicinity property remediation only); Gunnison, Colorado; Naturita, Colorado; and Rifle, Colorado (two sites). In addition, remedial action will begin at Maybell, Colorado, and Slick Rock, Colorado (two sites), during 1995. The environmental protection programs at these sites comply with all applicable state and federal environmental regulations. Remedial action activities have been evaluated for environmental impact and to ensure that they meet all regulatory requirements. General environmental protection activities include monitoring and discharge of liquid effluents (including storm waters) to surface waters, monitoring of air emissions, and proper storage, disposal, and reporting of hazardous materials used at the sites.

Environmental monitoring at sites undergoing surface remedial action consists of airborne radionuclide monitoring, external penetrating gamma radiation monitoring, fugitive dust monitoring, and ground and surface water monitoring. Internal and external compliance assessments are routinely performed of these activities. Complete training and awareness for management of environmentally hazardous materials is provided to Project managers, supervisors, and selected technical staff. Waste minimization and material recycling occur when feasible.

In accordance with the U.S. Department of Energy (DOE) policy, UMTRA Project sites are required to comply with federal and state environmental requirements. Accordingly, the sites comply with regulations implementing the Clean Water Act, the Clean Air Act, the Resource Conservation and Recovery Act, and the Emergency Planning and Community Right-to-Know Act (EPCRA), as well as DOE Orders. Where applicable, site-specific permits are obtained from the appropriate regulatory agencies.

A. Chemical Storage and Waste Management Programs

1. Emergency Planning and Community Right-to-Know

Each UMTRA Project site complies with the EPCRA requirements by developing a site inventory for all materials stored on the site in excess of 10,000 pounds ( 4540 kilograms) or in excess of the threshold planning quantities for extremely hazardous materials. The inventories (which include diesel fuel, oil, sulfuric acid, other automotive maintenance fluids, and uranium mill tailings) are submitted to the state emergency response commission, the local emergency planning committee, and the local fire department for each site. All sites comply with the EPCRA requirements by developing and submitting Tier II reporting forms. 
2. Waste Minimization/Recycling

All chemical products used on the site are either consumed in the remediation process, reused, or recycled to ensure overall waste minimization. Local qualified vendors are contracted to recycle most of the bulk products (oil, fuels, antifreeze, greases, batteries, etc.) on a scheduled basis. Other products, such as spray paint, are not discarded unless their containers are empty. Site surveillance ensures that waste minimization and recycling activities are implemented.

B. Air Quality Programs

1. Nonradiological Monitoring

National Emissions Standards for Hazardous Air Pollutants (NESHAP) compliance is maintained for asbestos emissions during demolition and excavation activities when asbestos is discovered. The state where the site is located issues an asbestos air quality permit prior to abatement. Strict dust control, continuous monitoring, and proper asbestos work practices are implemented during abatement. Current site-specific permits/plans covering asbestos management include asbestos removal permits at the Naturita (94MO1620A and 94MO1919A) and Gunnison (93GU2038A) sites for asbestos notification and management.

All the Colorado sites comply with the Colorado total suspended particulates (TSP) monitoring requirements for fugitive dust. The state of Colorado has adopted the federal TSP levels. Three TSP monitoring stations are located at the Rifle site and two stations are located at the Gunnison site. The TSP monitoring stations are operated under approved protocols that meet Colorado requirements. The TSP monitoring occurs every 3 days at the Rifle site and every 6 days at the Gunnison site. Quarterly reports are submitted to the Colorado Department of Health $(\mathrm{CDH})$.

Site-specific air quality permits issued by the CDH include the Grand Junction air permit for the disposal site (88ME247); the Naturita air permit for the processing site (94MO210F); the Gunnison air permits for the processing (90GU472F-1) and disposal (90GU472F-2) sites; and the Rifle air permits for the processing (88GA191) and disposal (88GA190) sites.

2. Radiological Monitoring

Environmental monitoring is also conducted at all sites for airborne radionuclides and external penetrating gamma radiation. Continuous airborne particulate sampling stations have been established at locations adjacent to the sites and in nearby residential areas. Airborne particulate samples are analyzed for gross alpha particles, radium-226, and thorium-230. Radioactive radon gas monitoring is conducted continuously at some of the same locations airborne particulates are sampled. External penetrating 
gamma radiation monitoring is performed continuously at locations adjacent to the sites and in nearby residential areas using thermoluminescence dosimeters.

C. Water Quality Programs

1. Surface Water Discharges

At all UMTRA Project sites, surface water runoff/run-on is controlled by the use of contoured drainage ditches. These ditches route storm waters to fully lined retention basins. Little of the water collected in these basins is ever discharged. Instead, the collected water is usually allowed to evaporate or is used on the site for construction water and dust suppression.

The state of Colorado issues Colorado Discharge Permit System (CDPS) permits for surface water discharges at Colorado sites. CDPS wastewater discharge permits have been issued for releases from the following Colorado sites: Rifle processing sites (CO-0042552) and disposal site (CO-0042757); Gunnison processing site (CO-0042889) and disposal site (CO-0043401); and Grand Junction disposal site (CO-0042391).

In addition, the state of Colorado has issued the following storm water permits: Gunnison processing site (COR-30193), disposal site (COR-30264), and haul road (COR-30265); Rifle processing sites (COR-030207, COR030266) and disposal site (COR-030194); Grand Junction disposal site (COR-30192); and Naturita processing site (COR-030880).

In 1995, the Grand Junction wastewater and storm water permits will be renewed as a single permit. Appropriate CDPS permits have been applied for and are pending for the Maybell and Slick Rock sites.

\section{Spill Prevention Control and Countermeasures Plans}

Spill Prevention Control and Countermeasures Plan requirements for spill response, reporting, and secondary spill containment systems for bulk chemical (primarily oil and fuel) storage areas are prepared for each UMTRA Project site. Secondary containment systems consisting of earthen berms around aboveground storage tanks and around drum storage areas are designed and constructed to provide adequate capacity to control spills.

\section{Septic Tanks}

The Grand Junction site uses a septic tank at the disposal site to contain grey water from sanitary facilities. Sewage systems were installed to local code at the processing site and disposal sites for the Gunnison site. There is a septic tank at the New Rifle processing site that is being maintained per state and local requirements. 
4. Surface Water and Ground Water Monitoring

Surface waters adjacent to UMTRA Project sites are monitored quarterly and during storms that cause runoff from the sites. Water samples are analyzed for radium-226 and thorium-230. This monitoring is not performed to assess the quality of the water, but to monitor the effects of construction activities. The monitoring results are compared to previous results and also to guidelines given in DOE Order 5400.5 .

Surface waters in the vicinity of the sites are also sampled and analyzed for constituents listed in the proposed EPA ground water protection standards to monitor the quality of surface waters near the sites.

Ground water monitoring is also conducted routinely to observe changes in ground water quality prior to, during, and after remedial action. Ground water samples are analyzed for major ions and the parameters listed in the proposed EPA standards. Annual water sampling and analysis plans are prepared for all UMTRA Project sites, including those where surface remedial action has been completed or not yet begun. 